\title{
OBTENÇÃO DE PROTEÍNA MICROBIANA PARA RAÇÃO ANIMAL A PARTIR DO HIDROLISADO DE BAGAÇO DE CANA-DE-ACÚCAR
}

SUIELD BVEGREUTU CRUR

Engenheiro-Agronomo

Orientador: JOSÉ PAULO STUPIELLO

\begin{abstract}
Dissertą̧ão apresent ada à Escola superior de Agricultura "luiz de Queiroz" da universidade de são Paulo, para obtencão do titulo de Mestre em Agronomia. Área de concentracão: Ciência e Tecnologia de Alimentos.
\end{abstract}

P I R A C I C A B A

Estado de Şo Paulo - Brasil

Maio -1990 
Ficha Catalográfica preparada pela Seçăo de Livros da Divisăo de Biblioteca e Documentação - PCAP/USP

Cruz, Sueli Negretti

C957o Obtenção de proteína microbiana para raçăo animal a partir do hidrolisado de bagaço de cana-de-açucar. Piracicaba, 1990.

$89 p$.

Diss. (Mestre) - ESALQ

Bibliografia.

1. Animal doméstico - Nutriçăo 2. Bagaço de canade-açucar hidrolisado 3. Levedura - Crescimento 4. Le vedura em raçăo 5. Proteina microbiana em raçăo 6. Ra çăo - Enriquecimento protéico I. Escola Superior de $\underline{A}$ gricultura Luiz de Queiroz, Piracicaba

CDD 664.1228 


\section{OBTENÇূূ DE PROTEÍNA MICROBIANA PARA RAÇÃO ANIMAL A PARTIR DO HIDROLISADO DE BAGAÇO DE CANA-DE-AC̣ÚCAR}

Aprovada em: 24.08.1990

Comissão Jul gadora:

Prof. Dr. José Paulo Stupiel $10 \ldots \ldots \ldots \ldots \ldots$ ESALQ/USP

Prof. Dr. Jorge Horii ................ ESALQ/USP

Prof. Dr. Luiz Gonzaga de Souza ............. FCAB/UNESP

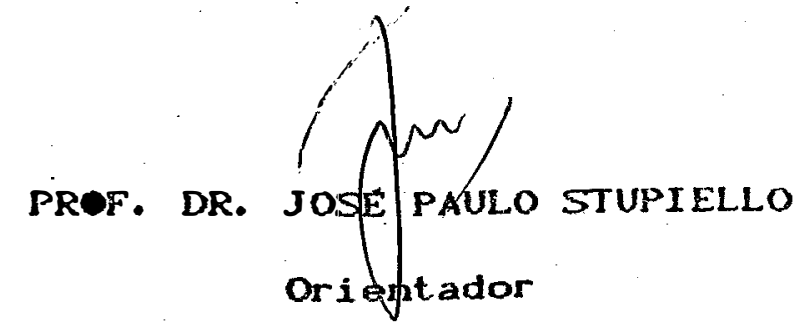


ii.

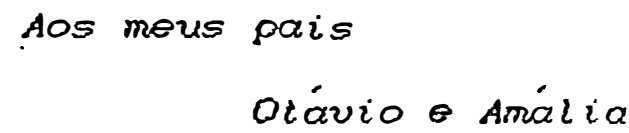

Ao meu marido

Vivaldo

Aos meus filhos Edrardo, Flavio, Adriana e Renato 


\section{AGRADECIMENTOS}

Ao Professor Dr. José Paulo Stupiello, orientador dessa dissertação, pela dedicaçăo e pela cuidadosa revisão critica do texto original.

- Aos Professores Dr. Jorge Horii, Dr. Marco Antonio A. Cesar, Dr. Fernando V. Novaes, Dr. João G. Brasil Caruso, Dr. Luiz E. George Barrichelo e Dr. Nadir "Almeida da Glória pela atenção dispersada durante a execução deste trabal ho.

- Aos funcionários Edson Franzoni, Sylvino L. Torrezan, Rosemary L. da S. Mandro e Jose Emflio Q. de Al meida pela col aboração mas análises de laboratório.

- A Gislaine M. M. de Oliveira pelos serviços de datilografia prestados.

- Aos funcionários do Departamento de Tecnologia Rural pela colaboração em especial ao Sr. Constante Christofoletti.

- A todos gue direta ou indiretamente contribuiram para a realização deste trabalho. 
iv.

\section{NDI CE}

Página

LISTA DE FIGURAS .................... vii.

LISTA DE TABELAS .................... viii.

LISTA DE ABREVIATURAS E SI MBOLOS .............

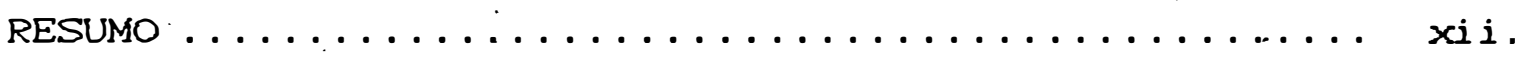

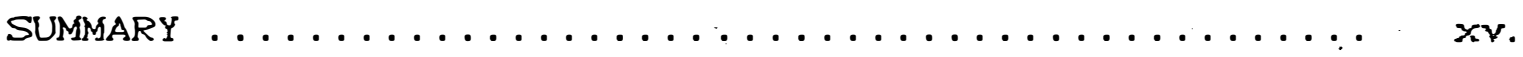

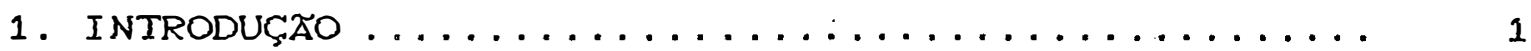

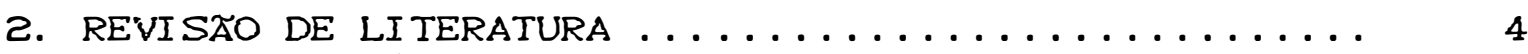

2.1. Bagaço de Cana-de-açúcar .............. 4

2.1.1. Composição química do bagaço ......... 4 4

2. 2. Hidrólise do Bagaço .................. g

2.2.1. Reações de hidrólise .............. g

2.2.2. Produtos da decomposição de açúcares .. 14

2. 3. Conversão de D-xilose e D-xilulose-5 Fosfato por Levedura ........................ 16

2. 4. Fermentaçăo ..................... 18

2. 4.1. Misturas de pentoses e hexoses ....... 18

2. 4. 2. Hidrol ísados 1 ignocel ul osicos ....... 21

2. 5. Levedura ...................... 27

2.5.1. Consideraçס̃es gerais ............ 27

2. 5.2. Composiçăo qú mica da levedura ....... 30

2.5.3. Valor nutritivo da levedura ........ 35

2.5.4. Efeito tóxico da levedura .......... 40 
Página

3. MATERT AL E METODOS ..................... 43

3.1. Materia-Prima ................. 43

3. 2. Substratos para Fermentação ............. 43

3.2.1. Extrato de bagaço ..............43

3.2. 2. Licor de Bagaço ................ 44

3. 3. Determinaçธ̃es Analiticas ................ 44

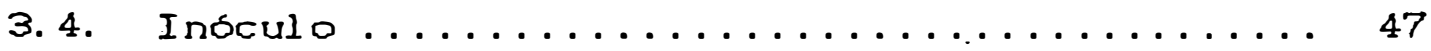

3. 5. Suplementação de Sais dos Substratos ........ 48

3. 6. Descrição dos Equi pamentos .............. 48

3.7. Descrição de um Ensaio Tŕpico ............ 49

3. 8. Variação do Ensaio Típico .............. 51

3. 9. Cáloulo dos Rendi mentos .............. 52

3. 9.1. Rendimento do substrato $\left(n_{s}\right) \ldots . . . .52$

3. 9. 2. Rendimento biologico (n) ........ 52

3.10. Cálculo das Eficiencias ............. 52

3.10.1. Eficiencia do processo biológico (E).. 52

3.10.2. Eficiencia do processo em relação ao açúcar total do substrato $\left(\varepsilon_{s}\right) \ldots \ldots . . .53$

3.11. Cálculo da Razão de Crescimento Celular $\left(R_{x}\right) \ldots 53$

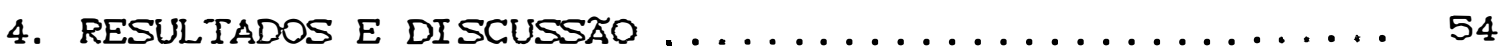

4.1.Pre-Hidrolise ..................... 54

4. 2. Ensaios ....................... 55 
Página

4.2.1. Ensaio I (sem aeração) ........... 56

4.2.2. Ensaios II, III, IV e V (com aeração) .. 60

4.2.3. Ensa:ios VI, VII, VIII e IX com aeraç̃o e suplementação de sais $\ldots \ldots \ldots \ldots \ldots 68$

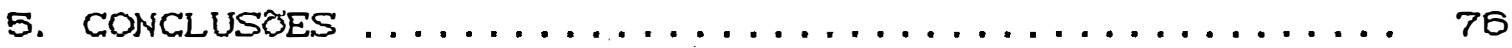

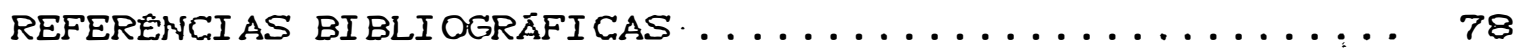


vii.

\section{LISTA DE FIGURAS}

Figura

Página

1 Metabolismo de D-xilose em bacterias e D-xilose

em leveduras (KLING et alii, 1985). ........ 17

2 Esquema das análises realizadas em 'um ensaio

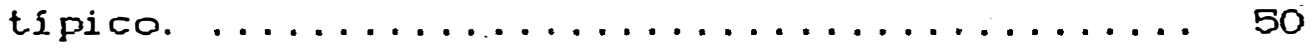


viii.

\section{LISTA DE TABELAS}

Tabela

Página

1 Composição em monossacarídeos das hemiceluloses - o residuo após a extração, expressos em matéria seca. ........................... 10

2. Composição do bagaço em ami noácidos e o resíduo após a extração da hemicelulose, expressos em

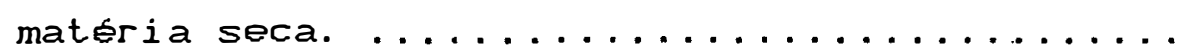

3 Crescimento de várias culturas de levedura em hidrolisados. 1 ignocel ulósicos durante 24 horas. 23

4 Composição elementar de leveduras comerciais e

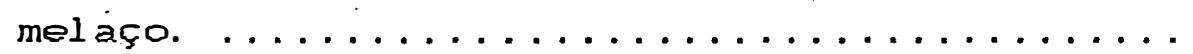

5 Composição em amì noácidos essenciais de leveduras alimentares comerciais. ............ 33

6 Umidade \% bagaço, Brix, pH, açúcar total (AT) e AT\% bagaço do extrato do digestor e do licor. . 46

7 Teores de nutrientes minerais no extrato e no

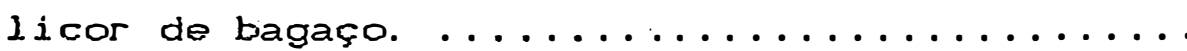

8 Açúcares do licor de bagaço. .............

9 Condiç̧̋es experimentais do Ensaio I Csem aeraçà.

10 Valores de $M_{x f} ; M_{x} ; A_{x} ; A_{c} ; A_{c} \%$ de AT no En-

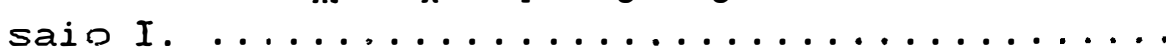

11 Valores de $R_{x} ; \eta_{s}, \eta, \varepsilon e \varepsilon$ para o Ensaio I. 
ix.

Tabela

Página

12 pH e acidez acética do Ensaio I. ..........

13 CondiçBes experimentais dos Ensaios II, III, IV e v ccom aeraçăo). ................... 60

14 Valores de $M_{x f} ; M_{x} ; A_{r} ; A_{c} ; A_{c} \%$ de AT nos Ensaios II, III, IV IV.$\ldots \ldots \ldots \ldots \ldots \ldots$

15 Valores de $R_{x}, \eta_{s}, \eta, \varepsilon e \varepsilon_{s}$ para os Ensaios

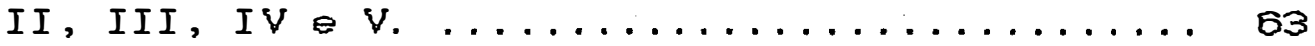

16 Dosagens de Etanol no Ensaio IV $(\mathrm{ml} / 100 \mathrm{ml}) . \ldots 64$

$17 \mathrm{pH}$ e acidez acetica dos Ensaios II, III, IV e v. ....................... 6 ?

18 Condiçช̃es experimentais dos Ensaios VI, VII, VIII e IX (com aeração e suplementação de sais) 68

19 Valores de $R_{x} ; \eta_{s}, n, \varepsilon_{s}$ e $\varepsilon$ para os Ensaios VI, VII, VIII. e IX. ................ 69

20 Valores de $M_{x f} ; M_{x} ; A_{T} ; A_{c} ; A_{c} \%$ de AT nos Ensaios VI, VII, VIII e IX. ............

$21 \mathrm{pH}$ e acidez acética dos Ensaios VI, VII, VIII e IX. ......................... 73

22 Rendimento em massa seca de cellul as de levedura em relação ao açúcar tótal do extrato do digestor e do licor (\%). CMédia de 3 repetições para

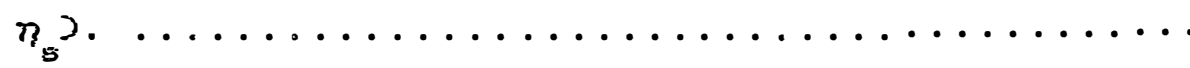


$x$.

Tabela

Página

23 Rendimentos medios em leveduras em relação aos açúcares totais do licor e extrato em $\mathrm{kg}$ por

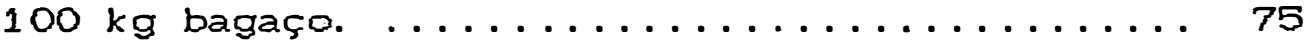




\section{LISTA DE ABREVIATURAS E SIMBOLOS}

$A_{c}$ - Açúcar total consumido na fermentação, calculado como açúcar invertido (mg).

Ar - Açúcar residual da fermentação, calculado como açúcar invertido (mg).

AT - Açúcar total calculado como açúcar invertido (mg).

$A T_{1}$ - AT para extrato.

$A T_{2}$ - AT para licor.

$M_{x}$ - Massa de cellulas de leveduras seca obtidas na fermentação (mg).

$M_{x o}$ - Massa inicial de células de leveduras seca (mg).

M ${ }_{x f}$ - Massa de cellulas de leveduras seca no firial da fermentação (mg).

$R_{x}$ - Razão de cresciment.o celul ar $(\%$.

$U_{x}$ - Umi dade do fermento prensado (\%).

$V$ - Volume de substrato $(\mathrm{ml})$.

$\varepsilon \quad$ - Eficiência do processo biológico. Eficiencia do processo relacionada ao açúcar consumido $(\%)$.

$\varepsilon_{s}$ - Eficiência do processo reelacionada ao açúcar total do substrato $(\%)$.

$n$ - Rendimento do processo biológico. Rendimento em células relacionado ao açúcar consumido (\%)

$\eta_{s}$ - Rendimento em células relacionado ao açúcar total do substrato $\%$. 
xi i.

\title{
OBTENC̣̃̃ DE PROTEÍNA MICROBIANA PARA RAC̣̃̃ ANIMAL \\ A PARTIR DO HIDROLISADO DE BAGAC̣O DE CANA-DE-ACÚCAR
}

\author{
Autora: SUELI NEGRETTI CRUZ \\ Orientador: PROF. DR. JOSE PAULO STUPIELLO
}

RESUMO

- o presente trabalho teve por objetivo estudar a possibilidade de crescimento da levedura saccharomyces cerevisiae, especie de levedura de fácil manuseio e disponibilidade nas destilarias, em licor, após os tratamentos preconizados para fermentação em hidrolisados lignocel ul ósicos.

A levedura assim obtida seria destinada à ração animal.

Procurou-se comparar o rendimento da levedura cresçendo no licor de bagaço de cana-de-açúcar e o rendimento da levedura crescendo no extrato de bagaço de cana-de-açúcar.

O extrato de bagaço foi obtido pelo método do digestor a frio e o licor pelo método di autoclavagem do bagaço úmido à temperatura de $170^{\circ} \mathrm{C}$ por tirinta minutos, numa relação bagaço/água 1:10 (peso secopvolume) em um digestor rotativo. 
xiii.

- extrato de bagaço contém os açúcares residuais do bagaço e o licor os açúcares residuais mais os açúcares provenientes da pré-hidrólise do bagaço.

0 1icor apresentou $315 \mathrm{ppm}$ de furfural, produto da decomposição das pentoses. Para reduzir o teor de furfural e outros compostos voláteis gue inibem a fermentação, - licor foi submetido a um tratamento apss o qual o teor de furfural se reduziu a $36 \mathrm{ppm}$.

Foram realizadas determinaçธes analiticas de Brix, açúcares redutores totais, $\mathrm{pH}$, nitrogenio, fósforo, potássio, cálcio e magnésio no extrato e no 1 icor.

A inoculação do extrato e do licor foi feita com $1 \%$ de fermento prensado. Os ensaios foram de 24 horas em frascos Erlenmeyers agitados: 1 s sem aeração; 2 s somente com aeração; 3) com aeração e suplementação de nutrientes. Os sais utilizados na suplementaçăo foram uréia e fosfato monobásico de potássio.

Após a centrifugação do vinho determinou-se a matéria seca de celluilas de levedura e no sobrenadante, pH, açúcares residuais e etanol. Foram calculados rendimento em levedura, eficiencia do processo e razão de crescimento celular.

Verificou-se que a levedura cresce no pre-hidrolisado de bagaço tratado. Existem substâncias desconhecidas no licor que inibem fermențação. Os melhores rendimentos em celulas de levedura no 1 icor foram obtidos com aeração e suplementação de nitrogenio e potássio. Nas condiç̧̋s em que 
xiv.

foram realizados os ensaios, o licor com aeração e suplementação de nutrientes apresentou maior rendimento que o extrato em leveduras. 
XY.

\title{
OBTAINING MICROBIAN PROTEIN FROM HYDROLYSATE OF SUGAR CANE BAGASSE FOR ANIMAL FOOD
}

\author{
Author: SUELI NEGRETTI CRUZ
}

Adviser: PROF。DR, JOSE PAULO STUPIELLO

SUMMARY

The purpose of this work was to study the growing possibility of saccharomyces cerevisiae, yeast. of easy handling and availability in the distilleries, in liquor, after recommended treatments for fermentation in lignocellulosic hydrolysates. The yeast obtained in this manner would be destined to animal food.

The yield of yeast growing in liquor of sugar cane bagasse was compared to the yield of yeast growing in the extract of sugar cane bagasse.

The bagasse ext.ract was obtained by the cold digester method and the 1 iquor by the wet bagasse autoclave method at the temperature of $170^{\circ} \mathrm{C}$ for thirty minutes at 1:10 bagasse/water ratio (dry weight/volume) in a rotative digester.

The extract of bagasse contains the residual sugars of the bagasse and the liquor contains the residual 
xvi .

sugars of the bagasse and the sugars from the pre-hydrolysis of the bagasse.

The liquor : presented $315 \mathrm{ppm}$ of furfural, product of pentoses decomposition. To reduce the amount of furfural and other volatile compounds which inhibit fermentation, the liquor was submitted to a treatment. After which the amount of furfural was reduced to $36 \mathrm{ppm}$.

Analytical measurement.s of Brix, total reducing sugars, pH, nitrogen, phosphorus, potassium, calcium and magnesium were made in the extract and in the 1 iquor.

The jeast inocul um used was $1 \%$ of pressed backery yeast. The essays were of 24 hours in agitated Erlenmeyers flasks: 1$)$ airless without nutrient supply; 2) only with air; 3) with air and nutrient supply. The inorgaric salts utilized in the essays were urea and potassium phosphate monobasic.

The dry matter of yeast cells was determined after the wine centrifugation, and the $\mathrm{pH}$, residual sugars and ethanol were determined in the supernatant. Yield of yeast, process efficiency and growth rate of yeast were also calculated.

It was found that the yeast grows in the treated pre-hydrolysate of bagasse. There are unknown substances in the liquor that inhibit fermentation. The best yield in yeast cells in the liquor were found in the treatment with aeration and addition of nitrogen and potassium. In the condition that the essays were carried 
xvi i.

out, the liquor with aeration and nutrients supply showed higher yeast cells yield than the extract. 


\section{INTRODUÇ.̃̃O}

Da fabricação do álcool e ou açúcár, a partir da cana-de-açúcar, tem-se quatro residuos: bagaço, torta, vinhaça e mel final. ̃̃ medida que esses residuos são explorados economicamente, eles se tornam subprodutos da cana-de-açúcar. Assim, a tórta é considerada um subproduto porque é utilizada principalmente na recuperação de solos fracos; vinhaça, na fertirrigação o mel final, na produção do álcool. o bagaço é a fração resultante da moàgem da cana, da qual foi extraf do o cal do e é também um subproduto, sendo cerca de $70 \%$ dessé bagaço utilizado na geração de energia para a própria fabricação do açúcar e do álcool.

O bagaço (50\% de umidade) corresponde cerca de 30\% do peso da cana. Considerando a produção do álcool em uma destilaria autónoma de.75 litros por tonelada de cana, tem-se para cada litro de álcool uma produção de $4,0 \mathrm{~kg}$ de bagaço, dos quais cerca de $1,2 \mathrm{~kg}$ de bagaço é excedente. Nos Estados de Alagoas e Pernambuco as sobras de bagaço aumentam a cada ano. Em Pernambuco ainda existe um pequeno mercado para uso de bagaço na fabricação de papel, queima em caldeira de refinaria de açúcar e das fábricas de tecido. Em São Paulo o bagaço é aproveitado para a produção de celul ose 
e papel, furfural, conglomerado, volumoso nas raçðes para animais em confinamento e insumo energético em outras indústrias. Essas indústrias modificaram suas caldeiras para queimar bagaço de cana.

As usinas e destilarias das Regizes de Ribeirão Preto e Piracicaba, têm vendido bagaço à preço que variam entre $70-90 \%$ do val or da tonelada de cana.

O maior problema é o transporte do bagaço que "in natura", corresponde a conduzir a metade do seu peso em água. O seu custo pode não ser encorajador quando se considera transporte de bagaço a longas distâncias, necessitando as usinas se aparelharem para beneficiamento do bagaço (secagem e enfardamento) de modo que ele chegue ao consumidor a preços mais competitivos.

Quanto as indústrias, que poderiam utilizar o bagaço, se localizam muito afastadas da usina, uma das sugestres seria aproveitar o bagaço excedente na produção de protelnas microbianas, em instalaçzes anexas às usinas e destilarias, aproveitando o açúcar residual do bagaço que é da ordem de $2-4 \%$

Segundo HARRISON (1971) um crescimento aeróbjco de leveduras como Saccharomyces cerevisiae ou 5 . uvarum ou Candida uiilis pode conduzir à obtençăo de um rendimento de massa celular seca de $47,5 \mathrm{~g}$ para cada $100 \mathrm{~g}$ de gli.cose ou na prática, a cerca de $43,2 \mathrm{~g}$, o que seria correspondente a $91 \%$ do teorico. Assim se a recuperação do açúcar do bagaço for da ordem de $3 \%$ haverá a possibilidade de se produzir 
cerca de $1,3 \mathrm{~kg}$ de materia seca porcento de bagaço tratado ou $3,9 \mathrm{~kg}$ por tonelada de cana aproximadamente. Esta protelna microbiana obtida poderá ser utilizada como suplemento de ração para animais para atender à demanda do produto pela pecuária nacional.

o objetivo desse trabal ho foi estudar a possibilidade de crescimento da levedura prensada Saccharomyces cerevisiae, especie de levedura de fácil manuseio e.disponivel nas destilarias, em licor, produto da autoclavagem do bagaço, após os tratamentos preconizados para fermentaçăo em hidrolisados 1 ignocelulósicos. 


\section{REVISAO DE LITERATURA}

\subsection{Bagaço de Cana-de-açúcar}

\subsubsection{Composiçåo química do bagaço}

o bagaço é o resíduo fibroso da cana-dë-açúcar após a moagem e extração do caldo, sendo constituído de água, fibras e pequenas quantidades de sólidos solúveis (PATURAU, 1969), nas proporçסes:

\footnotetext{
Agua ....................... . 46-52\% (médi a $49,0 \%$

Fibra ................... 43-52\% (média $48,7 \%$

Solidos solúveis (maioria açúcares) ... 2-6 \% (média 2, $3 \%$ )
}

Para PATURAU (1969) a composição quilmica do bagaço, varia com a variedade de cana, maturaçăo, método de colheita e com a eficiência de extraçăo.

Para VALSECHI (1964) a composição química do bagaço, varia com um grande número de fatores ligados à própria composição da cana, à natureza e a intensidado dos metodos de extraçäo; e para o bagaço em depósito. com o processo de armazenamento e o tempo de espera para o 
5.

processamento industrial. De um modo geral, pode-se dizer que o bagaço fresco, tal como sai da última moenda das usinas de açúcar, possui, aproximadamente:

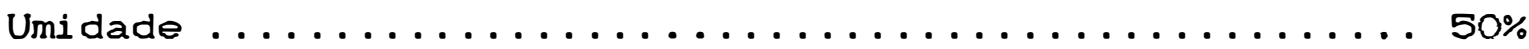

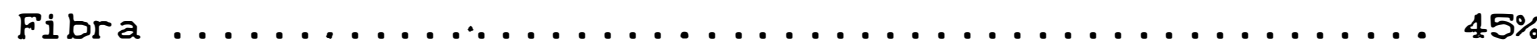

Material solúvel em água .................... $5 \%$

A fibra do bagaço é um composto insolúvel em água, constituido principalmente de celulose, pentosanas e lignina (VALSECHI, 1964 e PATURAU, 1969 ) ou de celulose, hemicelulose e lignina CDELGADD et alii 1986 INSTITUTO CubANO DE INVESTIGACIONES DE LOS DERIVADOS DE LA CAAAA DE AZÚCAR, I CI DCA, 1986 ).

A celulose $\Leftrightarrow$ um polissacarídeo de fórmula geral $\mathrm{CC}_{6} \mathrm{H}_{10} \mathrm{O}_{5}$ In e é o principal constituinte dos tecidos vegetais (PATURAU, 1969). E insolúvel em água, solventes orgânicos e soluçđes alcalinas, com apreciavel resisténcia ao efeito de agentes oxidantes CDELGADO et alii 1986 e ICIDCA, 1986). Raramente ocorre na natureza em estado puro, mas intimamente ligado à lignina, pentosanas, gomas, taninos, gorduras, matérias corantes, etc (PATURAU, 1969 ).

Segundo PATURAU, (1969), a celulose é classificada, em relação ao seu grau de solubilidade em soda cáustica, em:

$\alpha$ celulose - insolúvel em soda a $17,5 \%$, a temperatura ambiente. 
6.

$\beta$ celulose - solúvel em soda a $17,5 \%$ e facilmente precipitada em sol ução ácida.

$\gamma$ celulose - solúvel em soda à $17,5 \%$, não precipitada por ácidos, mas precipitada por álcool.

A a celulose é considerada como a forma pura de celulose, enquanto as solúveis em soda cáustica fíia à $17,5 \%$, comporem a hemicelulose.

As hemiceluloses abrangem um conjunto de polissacarideos diferentes cuja composição tem por característica a solubilidade em solventes, reatividade em meio aci do e decomposição em açúcares e füfural. Estas propriedades as diferenciam, analiticamente do resto dos componentes químicos do bagaço (DELGADO et alii 1986 e ICIDCA, 1986 ).

As hemiceluloses são compostas de unidades de pentoses (PATURAU, 1969 ).

Holocelulose é o termo usado para indicar ambas, celulose e hemicelulose, CPATURAU, 1969; DELGADO et alii 1986 e ICIDCA, 1986 ).

A lignina é um componente da fibra formada por um grupo de substancias de al to peso molecular, associado à celulose e hemicelulose. Sua estrutura química é largamente aromática, composta de anéis de benzeno, os quais contém alguns grupos 1 ivres e muitos grupos fenolicos metilados, mas a estrutura e tamanho dos polímeros ainda não estao bem estabelecidos (PATURAU, 1989 ). 
o ICIDCA, (1986), considera o bagaço do ponto de vista fisfco e do ponto de vista químico. Do ponto de vista fisico, o bagaço é constituido de quatro fraçzes:

Fibra ou bagaço .......................... $45 \%$

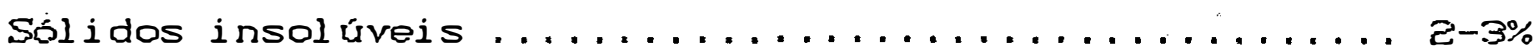

Sólidos solúveis ......................... . . . . . . .

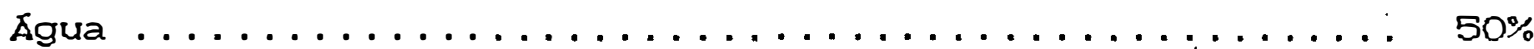

onde:

- a fibra é a fração sólida orgânica insolúvel em áçua presente no colmo da cana-de-açúcar e que se caracteriza por sua marcante heterogeneidade do ponto de vistia quf mico e morfologico.

- os solidos insolúveis, de natureza inorgânica, são constituidos fundamentalmente por terra, pedras e outros materiais estranhos, ainda que ém pequena quantidade participem da composição do bagaço.

- os solidos solúveis, fração que se dissolve em água, é composta de maneira fundamental por sacarose, cuja extração ulterior não seria economica à indústria açucareira e por componentes químicos como cera, mas em menor proporção.

- a água presente no bagaço é retida através de um mecanismo de absorção e capilaridade. O conteúdo de sólidos solúveis e umidade do bagaço estão relacionados com variáveis de operação industrial (IC.IDCA, 1986 ). 
Do ponto de vista gúmico, segundo DELGADo et alii (1986) e ICIDCA (1986), o bagaço é constitul do de:

Celulose ............................. $41-44 \%$ Hemi celulose ........................... 25-27\%

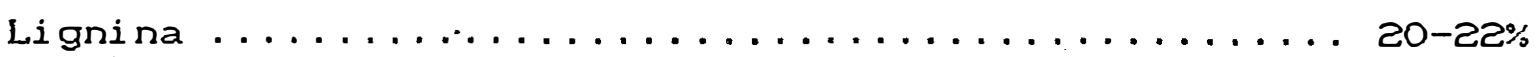
Componentes estranhos ................... maximo $10 \%$

Segundo os mesmos autores, a celulose é un polímero de D-glicose com Iigaçöes $\beta 1-4$ e peso molecular de 150.000 a 350.000.

As hemiceluloses, com predominância de D-xilanas, possuem cadeias poliméricas curtas e o peso molecular está entre 10.000 e 20.000 e a lignina, o terceiro componente de importância quantitativa no bagaço, é constituída de polímeros amorfos, reticulados de alto peso molecular e de natureza emineritemente fenolica.

O resto dos componentes do bagaço, em conjunto, podem chegar a 10\%: compostos solúveis em solventes orgânicos, ao redor de 3\% (ICIDGA, 1986 ) como resinas, ceras, gorduras, ácidos graxos, flavonas, fenóis CDELGADO el alii 1986); cinzas da ordem de $2-3 \%$ do bagaço e compostos solúveis em água, constituídos por sacarose, outros açúcares e polissacarídeos (DELGADO et alii 1986 e ICIDCA, 1986$).$ 
9.

\subsection{Hidrólise do Bagaço}

\subsubsection{Reaçôes de hidrólise}

Através de reaç̧es de hidrólise as cadeias de hemicelulose e celulose, componentes da fibra do bagaço, se decompßem dando açúcares mais simples ou monóssacarídeos.

A hidrólise da fraçăo hemicelulose chamada de pré-hidrólise (DELGADO et alii 1986). Os principais produtos da préhidrólise são xilose, arabinose, glucose e galactose (DU TOIT et alii 1984 e DELGADO et alii 1986) e ácidos urónicos (PATURAU, 1989 ).

A hidrólise da celulose é denominada de hidrólise principal e o produto da reaçăo são unidades de glicose. A pré-hidrólise. e hidrólise principal são favoreciclas por aumento de temperatura e pela presença de um catalisador ácido (DELGADO et aii 1986).

A fim de caracterizar o bagaço de cana-de- açúcar quanto aos monossacarideos, hemiceluloses e composição em aminoácidos, DU TOIT et alii (1984) realizaram hidrolise sucessivas no bagaço com ácido clorídico. A xilose foi - principal componente do hidrolisado enquanto glucose e galactose, presentes nas cadeias laterais das pentosanas. foram libertadas rapidamente. Este tratamento resultou na obtenção de $2.0 \mathrm{mg}$ de xilose (85\% do máximo teórico) e $44 \mathrm{mg}$ de glicose por grama de bagaço. Somente arabinose (2,8 mg/g) e galactose $(0,75 \mathrm{mg} / \mathrm{g})$ tamberm estavam presentes em quanti- 
dades detectáreis. Um total de $309 \mathrm{mg}$ de monossacarideos foram obtidos de 1 grama de bagaço por este tratamento (Tabela 1 ).

Tabela 1 - Composição em monossacarídeos das hemiceluloses e - residuo após a extração, expressos em materia seca.

\begin{tabular}{cccc}
\hline $\begin{array}{c}\text { MONOSSACARIDEOS } \\
\text { PRESENTES }\end{array}$ & VERDADEIRA & RELATIVA & ORIGINAL \\
(T) & (T) & (O) \\
\hline
\end{tabular}

\section{Henicel ul ose A:}

Arabi nose

Galactose

Xilose

$\mathrm{Gl}$ i cose

Total para hemicelulose A
3,98

0,37

54,66

7,79

66,80
5, 96

0,55

81,83

11,66

100,00
$0 ., 74$

0,07

10,08

1,44

12,33

\section{Hemicel ul ose B:}

Arabinose

Gal actose

Xilose

Gli cose

Total para hemicelulose B
16,76

5,32

43,69

19,18

84,95
19,73

6,26

51,44

22,57

100,00
2.50

0,99

8,13

3,57

15,19

\section{Residuo apos extraçao:}

Ar abi nose

Gal actose

2,67

0,80

Xilose

11,51

$\mathrm{Gl}$ i $\operatorname{cose}$

4,37

19,35
13,70
4,81
59,07
22, 42
100,00

1,62

0,48

6.96

Total para residuo

2,64

11,70

Fonte: DU TOIT et ali $\mathrm{T}(1984)$.

$T$ - Porcentagem de monossacarideos expressa como porcentagem verdadeira, recalculada como porcentagem da quantidade do material original hidrolisado.

$R$ - Porcentagem de monossacarídeos expressa como porcentagem relativa recalculada como porcentagem do total do monossacarideos presentes.

o - E a porcentagem da quantidade de material original prévia à extração de hemicelulose. 
Aminoácidos e peptideos ou protelnas também foram extraídos com álcali-diluido. Os resultados obtidos nesse trabaliho estão na Tabela 2.

Tabela 2 - Composiçăo do bagaşo em aminoácidos e o residuo após a extração dà hemicelulose, expressos em matéria seca.

AMI NOACI DOS

BAGACSO

$(\mu \mathrm{mol} / g), \%(g / g) \quad(\mu \mathrm{mol} / \mathrm{g}), \%(\mathrm{~g} / \mathrm{g})$

\begin{tabular}{|c|c|c|c|c|}
\hline Acido aspártico & 9,270 & 0,1234 & 2,608 & 0,347 \\
\hline Treonina & 0,412 & 0,0049 & - & - \\
\hline Serina & 6,276 & 0,0660 & 1,689 & 0,0178 \\
\hline Áci do glutâmico & 8,997 & 0,1320 & 2,866 & 0,0420 \\
\hline Prolina & - & - & - & - \\
\hline Glicina & 12,706 & 0,0955 & 3,420 & 0,0257 \\
\hline Al anina & 9,866 & 0,0879 & 2,984 & 0,0266 \\
\hline Cisteina & - & - & - & - \\
\hline Valina & 7,282 & 0,0853 & 2,968 & 0,0348 \\
\hline Metionina & 0,731 & 0,0109 & 0,090 & 0,0013 \\
\hline Isoleucina & 3,947 & 0,0518 & 1,191 & 0,0156 \\
\hline Leucina & 7,696 & 0,1010 & 3,118 & 0,0409 \\
\hline Tirosina & 1,228 & 0,0223 & - & - \\
\hline Fenilalanina & 3,148 & 0,0520 & 0,863 & 0,0142 \\
\hline Histidina & 1,276 & 0,0198 & 0,0261 & 0,0036 \\
\hline Lisina & 2,429 & 0,0355 & 1,319 & 0,0193 \\
\hline $\mathrm{NH}_{3}$ & 16,604 & 0,0283 & 8.517 & 0.0145 \\
\hline Arginina & 3,096 & 0,0539 & 0,453 & 0,0079 \\
\hline TOTAL & 94,964 & 0,9705 & 32,353 & 0,2989 \\
\hline TOTAL sem $\mathrm{NH}_{3}$ & 78,360 & 0,9422 & 23,838 & 0,2844 \\
\hline
\end{tabular}

Fonte: DU TOIT et alii, 1984.

NOTA: Quantidades nåo detectáveis em prolina, cisteina e residuos de treonina e tirosina. 
KLING et alii (1887) estudando a hidrolise enzimática no bagaço de cana-de-açúcar, pre-tratado por vapor a diferentes temperaturas e tempo de tratamento, seguido de. descompressão rápida do bagaço, encontraram um potencial no bagaço de $47 \%$ de açúcares redutores fermentesciveis caçúcares relacionados ao conteúdo de celuloses; $26 \%$ de açúcares redutores não fermentesciveis laçúcares relacionados ao conteúdo de hemicelulose); $23 \%$ de lignina e cerca de $4 \%$ de cinzas e outros residuos.

Ainda segundo esses autores, a hidrólise da fraçăo hemicelulose durante o tratamento por vapor envolve a solubilização da hemicelulose e parcial destruição dos açúcares redutores produzidos. A quantidade de açúcares redutores recuperados da hemicelulose pre-tratada é funça do tempo e da temperatura de tratamento. As condiços nas quais houve máximo rendimento na hidrólise de hemicelulose, foram:

$$
\begin{aligned}
& 220^{\circ} \mathrm{C}, 2 \text { minutos } \\
& 210^{\circ} \mathrm{C}, 3 \text { minutos } \\
& 200^{\circ} \mathrm{C}-8 \text { minutos } \\
& 190^{\circ} \mathrm{C}-10-15 \text { minutos }
\end{aligned}
$$

Aumentando o tempo de tratamento verificaram um incremento na hidrólise da hemiceluiose, com maior grau de degradação de açúcar. Há uma hidrólise incempleta da hemicelulose a oligossacarideos pelo tratamento a vapor, 
13.

verificada pela diferença entre os açúcares redutores não fermenticiveis recuperados da hemicelulose antes e após hidrólise, com ácido sulfúrico.

Segundo LACORTE et alii (1986) o tratamento do bagaço de cana-de-açúcar por vapor pode ser feito em operação continua ou em batelada e consiste de duas fases distintas:

1. Fase de auto-hidrỏlise: Nesta fase o bagaço de cana Cou orstro residuo 1 ignocelulósicos é acondicionado em uma câmara de pressão e submetido a elevada pressão e temperatura atraves de injeção de vapor. Nestas condiçZ̃es ocorre clivagem de radicais acetil da hemicelulose, com formação de ácido acético, que promove a hidrólise ácida da própria hemicelulose até suas hexoses e pentoses formadoras.

2. Fase de descompressão rápida: Nesta fase o vapor contido ná cámara de pressão, ao final do tratamento, repentinamente 1 iberado e a água contida nos fragmentos de bagaço vaporiza-se subitamente e sofre violen-. ta expansão, promovendo o "afrouxamento" do makerial.

Os processos fisicos como intumescimento. moagem, vaporizaçăo, etc., são utilizados para aumentar o tamanho dos poros, aumentando a área exposta, e para reduzir a cristalinidade da cel ulose (MENEZES \& HIOSHII, 1981 /82). 


\title{
2.2.2. Produtos da decomposiçấo de açúcares
}

\begin{abstract}
Nas reaç:Bes de hidrolise, o aumento da concentração do ácido, bem como da temperatura, aumenta a velocidade de reação de hidrólise e da decomposição de açúcares CDELGADO et ali 1986 e KLING et ali $i 1987$ ).
\end{abstract}

- produto da decomposição das hexoses é o hidroximetilfurfural e das pentoses é o furfural CHAJNY, 1981 ; JEFFRIES, 1983 e DELGADO et ali $i 19863$.

- hidroximetilfurfural pode ser decomposto posteriormente em ácido formico e ácido levulfnico CHANJY, $1981 \mathrm{~J}$, sendo o ácido fórmico altamente tóxico às leveduras (KATAGIRI, 1926$).$

A reação da pré-hidrólise ocorre em condiç̧es mais suaves que a hidrolise principal, por esse motivo, segundo DELGADO ei alii (1986) é conveniente realizá-la separadamente para evitar a decomposição de xilose em furfural.

Os hidrolisados ácidos de hemicelulose são substâncialmente mais dificieis de serem utilizados por microrganismos que as correspondentes misturas de açúcares puros. Esse fato é atribuido largamente à presença de. produtos de degradação de açucares, principalmente furfural (JEFFRIES, 19833.

Hidroximetilfurfural tambom afeta o croscimento de leveduras e segundo STAKHORSKAYA \& KATS (1968), a concentração limite de hidroximetilfurfural é $0,1 \%$ para crescimento de levedura em meio sintetico e 0, $2 \%$ em hidroli- 
15.

sados. Durante o crescimento, o teor de hidroximetilfurfural no meio é reduzido devido ao metabolismo pelas células de leveduras e pelas reaçßes do hidroximetilfurfural com os componentes do hidrolisado. Isso explica porque o nivel suportável de hidroximetilfurfural pela levedura é maior no hidrolisado que no meio sintético.

Segundo PETROVIC (1969) houve cresicimento, assimilação e atividade bioquímica de levedura em concentraçZes de $0,04-0,2 \%$ de furfural em meio sintético ou em hidrolisado e a adaptação ao aumento de concentraçăo se deu de modo gradual. As especies Torulopsis utilis, variedade major e $T$. utilis suportaram melhor concentraçzes mais aitas de furfural que Canaida utilis.

GUSAROVA (1970) observou que ofurfiral' inibiu a sintese protéca independentemente do estado fisiologico das cellulas de levedura, quando adicionado $0,1 \%$ ( vol $/$ vol 3 em cultura de Candida tropicalis. em meio sintético. Alguns experimentos realizados por LEONARD, em trabalho não publicado, segundo LEONARD \& HAJNY (1945), demonstraram que a destilação a vapor foi benếica à fermentação quando mais de $0,1 \%$ de furfural estava presente no hidrolisado e que outros compostos voláteis também foram removidos pela destilaçăo.

BANERJEE et aiti (1981) constataram que furfural, produto da reação de Maillard, inibiu crescimento e produça alcoblica por Saccharomyces cerevisiae, e as enzimas desidrogenases parecem ser as mais seristveis e provavelmente as responsáveis pela inibiçăo observada no 
16.

crescimento da levedura e produção alcólica. Não houvo inibiçăo de crescimento ao nivel de $0,5 \mathrm{mg}$ de furfural por mililitro de meio sintética.

Em prétidrolisado ácido de carvalho conercus falcatas, TRAN \& CHAMBERS (1986) identificaram como compostos inibidores da fermentaçăo por Pichia stipitis, furfural e ácido acético provenientes de hemicelulose, vanilina, aldeido siríngico, ácido vanílico e ácido siríngico provenientes de lignina e ácidos capróico, caprílico, pelargônico e palmitico, dos extrativos da madeira.

WEIGERT et alii (1988) estudaram a influencia da adição de furfural sobre o crescimento aeróbico da levedura Pichic stipitis e verificaram que o furfural adicionado foi rapidamente reduzido a álcool furfurilico. o furfural inibiu a respiração o produto alcool furfurilico influenciou a taxa de crescimento de Pichia stipitis. Conciuiram tamberm que a enzima alcooldesidrogenase foi a principal responsável pela redução de furfural a álcool furfurilico.

\title{
2.3. Conversão de D-xilose a D-xilulose-5 Fosíato por
} Levedura

\begin{abstract}
Em leveduras, o transporte de D-xilose para dentro da célula pode ocorrer por difusão facilitada ou por processo ativo (JEFFRIES, 1983). Uma vez dentro da célula de levedura, há dois possíveis caminhos para leveduras converter D-xilose a D-xilulose 5 fosfato, 0 qual $e$ um
\end{abstract}


intermediario no ciclo pentose fosfato: D-xilose pode ser submetida a uma reaçăo de redox a D-xilulose, com xilitol como um intermediário ou. D-xilose pode ser isomerizada diretamente a D-xilulose por D-xilose isomerase quando esta - adicionada. D-xilulose assim formada seria entăo fosforilada por D-xilulose quinase a D-xilulose 5 fosfato e canalisada para dentro do ciclo pentose fosfato CGONG et ai $i$ i, 19813 .

Segundo JEFFRIES, (1983), as bacterias geralmente empregam uma isomerase para converter D-xilose a D-xilulose, Figura 1-A, enquanto as leveduras e fungos executam a. mesma conversăo através de dois passos: de reduçăo e oxidação, Figura 1-B.

(A) Metabolismo de D-xilose em bactérias:

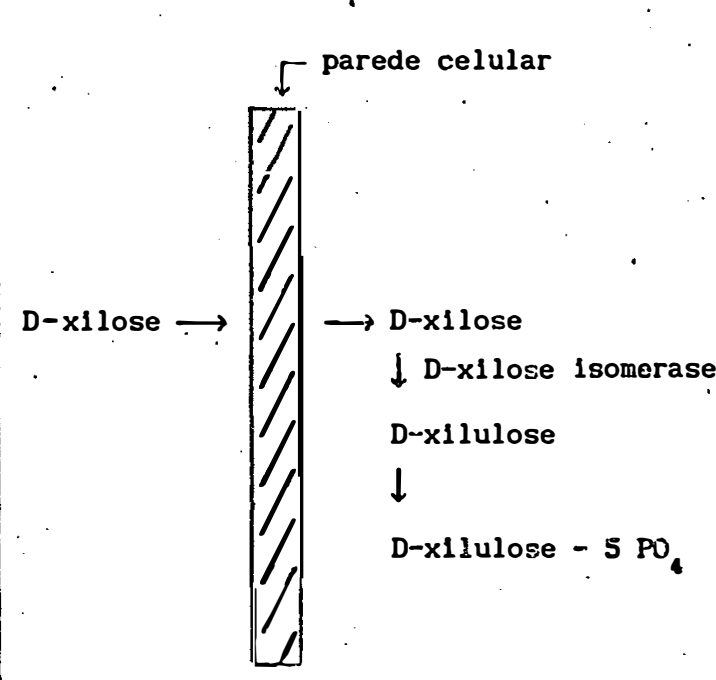

(B) Metabolismo de D-xilose ern leveduras.

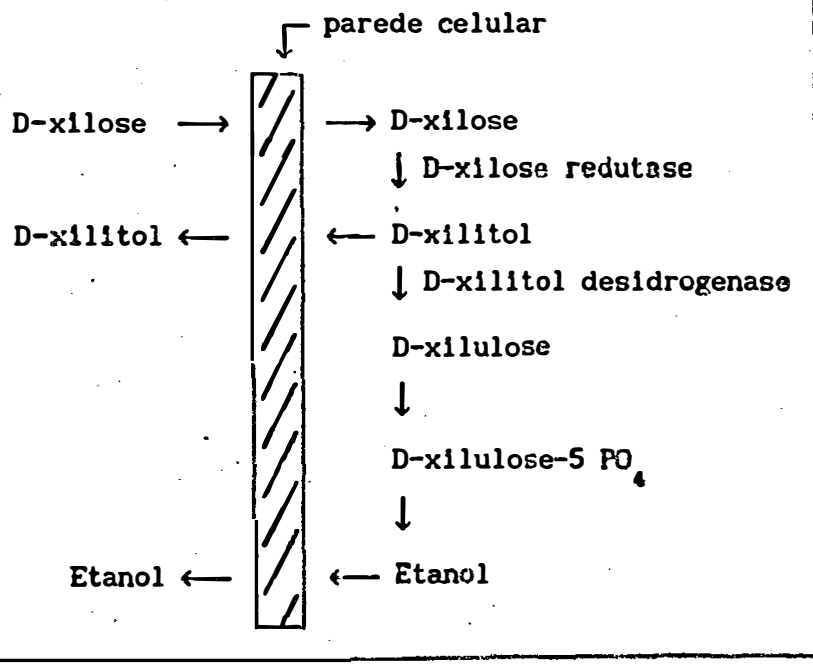

Figura. 1 - Metabolismo de D-xilose em bactérias e D-xilose em Ieveduras CKLING et ai $i$, $19853^{\circ}$. 
$!$

18.

Muitas leveduras são capazes de converter

D-xilose a D-xilulose aerobicamente, mas nenhuma é ainda conhecida como capaz de utilizar D-xilose anaerobicamente (JEFFRIES, 1983), exceto quando isomerases exógenas são adicionadas (GONG et alii, 1981).

Segundo JEFFRIES (1983), a enzima que cataliza a redução de D-xilose a D-xilitol, em leveduras e fungos, está na dependência de NADPH e D-xilitol desidrogenase está na dependência de NAD. A reaçăo de D-xilitol a D-xilulose é prontamente reversivel, ocorrendo a oxidaçåo de NADH com certo número de cetóses nas quais estão envolvidas D-xilulose, D-frutose e D-ribulose.

\section{4. Fermentaçåo}

2. 4.1. Misturas de pentoses e hexoses

A utilização de misturas de D-xilose com D-glucose e L-arabinose $\&$ de particular importáncia porque esses açúcares estão todos presentes em hidrolisados de residuos agrícolas e florestais.

Experimentos foram realizados por BORZANI \&. AQUARONE (1958) para determinar a influencia de arabinose sobre a fermentação de glucose por Saccharomyces cerevisiae NRRL Y-684. Os autores verificaram que a taxa de produção de $\mathrm{CO}_{2}$ aumenta na presença de arabinose como também o intervalo ótimo de pH da levedura, mas os rendimentos em álcool, com e sem arabinose são os mesmos. A reduça do pit do meio durante 
a fermentaçăo na presença de arabinose é menor do que a observada no meio de cultura contendo somente glucose. A concentração de arabinose decresce quando a levedura fermenta glucose. A arabinose não é fermentada pela levedura estudada. A inoculaçăo do meio contendo somente arabinose como a fonte maiogr de carbono resulta em quase completa destruiçăo da levedura. .

FANII \& KOHAN (1963) trabalhando com açucares puros, glucose ou xilose e com misturas dos mesmos açúcares verificaram que a levedura Torula utilis apresentava um comportamento distinto com relaçăo ao consumo desses dois açúcares. Os ensaios foram realizados com liquidos hidrolisados constituídos exclusivamente por hexoses e mist.uras de pentoses e hexoses em proporçoes distintas e com a mesma levedura. Os autores constataram que a cepa de Torula utilis é capaz de aproveitar hexoses e pentioses separadamente com al ta porcentagem de fermentaçăo; que em uma mistura de ambos os açúcares provenientes dos hidrolisados, a porcentagem de fermentaçăo diminue, chegando a um valor máximo de 60-65\%, depois de um processo de aclimatação; que ao predominar açúcares de 5 átomos de carbono no liquido, a levedura. fermenta em maior proporçăo estes açúcares que as hexoses e nos 1 lquidos com maior conteúdo de hexoses, há um maior aproveitamento das hexoses. Concluíram também quo nos 11 qui dos ensaiados, nos quais năo existiam substancias inibidoras que prejudicassem sensivelmente o processo, a mistura dia açúcares constituiu por si só, um fator inibitório. 
2o.

HSIAO et ali $i$ (1982) testaram quatro leveduras ¿Saccharomyces cerevisiae, Schizosaccharomyces pombe, candida utilis e Rhodotorula toruloidess para verificar sua habilidade em crescer e consumir D-glucose, D-xilose, D-xilulose e D-xilitol separadamente em várias misturas. D-glucose foi a melhor fonte de carbono para as quatro leveduras. D-xilulose foi consumida mais rapidamente que $D$-xilose $\cong$ D-xilitol pela quatro leveduras. 's. cerevisiae utilizou pouca $\mathrm{D}-\mathrm{xilul}$ ose, $S$. cerevisiae e Schizosaccharomyces pombe foram incapazes de usar D-xilose e D-xilitol para crescimento. Quando $D$-gl ucose e D-xilulose estavam presentes no meio de crescimento, o esgotamento de D-glucose não foi afetado pela presença de D-xilulose. Com R. toruloides e $S$. cerevisiae, D-xilulose começa a desaparecer do meio, somente quando D-glucose foi totalmente esgotada. Embora D-xilose fosse incapaz de prover o crescimentode S. cerevisiae, uma pequena porção de D-xilose foi. consumida e D-xilitol foi detectado no final do experimento, no meio em que D-glucose e D-xilose coexistiram. D-xilitol foi também detectado quando S. cerevisiae cresceu em D-xilulose.

O D-xilitol pôde ser detectado quando o substrato para $S$. cerevisiae foi D-xilose ou D-xilulose indicando que o caminho usado por Candida utilis para converter D-xilose a D-xilulose também existe em $S$. cerevisiae.

A razão do menor aproveitamento por 5 . cerevisiae de D-xilose para crescimento provavel mente é devida à baisa taxa de assimilação de D-xilose, indicada por CIRILLO (1968). 
GONG et alii (1983). em trabalho sobre conversão de pentoses por leveduras, observaram que a maioria das linhagens do genero Saccharomyces utilizou xilulose prontamente sob condiç̧es aeróbicas e fermentativas. Os produtos formados por leveduras do genero Saccharomyces, a partir de D-xilulose săo etanol, xilitol e D-arabitol. A quantidade e - tipo de produtos formados por este grupo de leveduras variam largamente dependendo da levedura e condiç̧es de incubaçăo empregados. Assim D-arabitol $\theta$ principal produto de S. cerevisice 26497 sob condiçర̃es aeróbicas e fermentativas. A levedura S. cerevisiae 4132 produziu aproximadamente igual quantidade de xilitol e D-arabitol sob condiços aeróbicas, mas produziu muito mais xilitol sob condiçoes fermentativas.

Segundo os mesmos autores a produção de arabitol proveniente de D-xilulose ou D-xilose tem por precursor a ribulose-5 fosfato e ribulose-5 fosfato tem a capacidade de derivar de D-xilulose-5. fosfato por fosfocetopentoepimerase (D-xilulose-5 fostato-3 epimerase).

\section{4.2. Hidrolisados 1 ignocel ul ósicos}

Soluçôs de açúcar preparadas por hidrólise ácida de material lignocelulósico têm sido usadas em fermentaçăo, em escala comercial, para produzir somente álcool etIlico ou levedura forrageira, (HAJNY, 1981 ).

LEONARD \& HAJNY (1945) listaram quatro fontes potenciais de substancias tóxicas que podem ser encontradas 
22.

em hidrólisados lignocelulósicos: produtos da decomposição de carboidratos, produtos da decomposição da lignina, extrativos presentes na matéria-prima e produtos de corrosão de. metal dos equipamentos, as quais afetam o rendimento da fermentação. Segundo os mesmos autores os rendi mentos em álcool obtidos com Torula utilis são comparáveis aos obtidos com Saccharomyces cerevisiae, mas requerem um maior tempo de fermentação. Dremonstraram ainda, trabal hando com Saccharomyces cerevisiae, que as dificuldades de fermentação podiam ser superadas com um tratamento prévio do hidrolisado como: aquecimento, adição de substancias redutoras como sulfitos, ácido ascórbico, cisteina; destilação com vapor do hidrolisado e adição de uma elevada proporçăo de inóculo, chegando a obter $80 \%$ de fermentação em 10 horas.

A aclimat.ação de levedura ao meio aumenta o rendimento em leveduras e a taxa de utilização de açúcar. CPETERSON et alii, 1945; JOHNSON \& HARRIS, 1948 a HAJNY, 19812. Leveduras de diversos gêneros foram testadas para verificar sua habilidade em crescer em hidrolisados e sua facilidade de acli matação a esses meios. Os resultados obti -dos por JOHNSON \& HARRIS (1948) encontram-se na Tabela 3 , para leveduras crescendo em hidrolisados com aproximadamente $5 \%$ de açúcar total.

SLININGER ei alii (1982) observaram que a levedura Pachysolen tannophilus tem a capacidade de converter D-xilose a etanol. Em culturas em batelada; contendo 50 g/1 de D-xilose e aeradas, conclufram que $11 \%$ da D-xilose foi 
23.

consumida para formar $4,4 \mathrm{~g}$ da biomassa produzida por 1 itro de cultura significando que $29 \%$ da D-xilose foi usada para manutenção das cellul as e ou formaçăo de produtos metabólicos al em de etanol $\bullet \mathrm{CO}_{2}$.

Tabela 3 - Crescimento de várias culturas de levedura em hidrolisados 1 ignocelulósicos durante 24 horas.

\begin{tabular}{|c|c|c|c|c|}
\hline \multirow{2}{*}{ LINHAGEM } & \multicolumn{2}{|c|}{ AŞUGAR INIGIAL } & \multicolumn{2}{|c|}{$\begin{array}{l}\text { RENDIMENTO DE } \\
\text { LEVEDURA }^{1}(\%)\end{array}$} \\
\hline & $\begin{array}{c}1 \stackrel{a}{-} \\
\operatorname{Transf} .\end{array}$ & $\begin{array}{l}12^{a} \text { a } 15^{a} \\
\text { Transf. }\end{array}$ & $\begin{array}{l}1 \stackrel{a}{ } \\
\text { Transf. I }\end{array}$ & $\begin{array}{c}12^{a} \\
\operatorname{Transf}\end{array}$ \\
\hline Torula utilis major & 78 & 82 & 25 & 42 \\
\hline Torula utilis thermophilis & 78 & 80 & 33 & 38 \\
\hline Torula utilis n으 2 & 78 & 82 & 25 & 38 \\
\hline Torula utilis $\mathrm{n}$ - 900 & 47 & 79 & 20 & 38 \\
\hline Torula utilis $\mathrm{n}^{\circ} 3$ & 50 & 88 & 22 & 37 \\
\hline Torula utilis n으 650 & 80 & 83 & 32 & 35 \\
\hline Torula utilis nㅇ 793 & 80 & 85 & 31 & 38 \\
\hline Torula utilis nㅇ 957 & 80 & 82 & 30 & 37 \\
\hline Candida albicans & 81 & 94 & 32 & 41 \\
\hline Candida arborae & 45 & 86 & 21 & 35 \\
\hline Candida arborae $n \div 197$ & 30 & 83 & 15 & 37 \\
\hline Candida arborae n 198 & 25 & 84 & 12 & 37 \\
\hline Hycotorula lipolytica & 10 & 84 & 5 & 36 \\
\hline Hansenula anomala & 50 & 80 & 21 & 33 \\
\hline Hansenula suaveolens & 25 & 82 & 11 & 34 \\
\hline Saccharomyces ananensis & 75 & 84 & 30 & 36 \\
\hline Sac. cerevisiae $\mathrm{n}^{\circ} 46$ & 50 & 83 & 22 & 30 \\
\hline Saccharomyces ellipsoideus & 60 & 80 & 27 & 35 \\
\hline Best yeast $n^{\circ} 2$ & 33 & 80 & 15 & 38 \\
\hline
\end{tabular}

Fonte: JOHNSON \& HARRIS, (1948).

${ }^{1}$ Baseada no açúcar total em soluçăo. 
24.

Iratamentos pelo calor foram testados a

diferentes concentraçōes hidrogeniónicas por PETERSON et alii (1945). As propriedades do meio resultante não foram significantemente diferentes. Houve apreciável destruição de açúcares redutores, quando o aquecimento foi realizado as mais baixas concentraçశes hidrogeniónicas (pH 8-10). Para ajustar o $\mathrm{pH}$ do licor foram usados, pelos mesmos autores, hidróxido de amónia que serve para elevar o $\mathrm{pH}$ e como fonte de nitrogénio; carbonato de cálcio, o qual apresenta a desvantagem de causar espuma excessiva e hidróxido de cálcio - qual evita formação de espuma, é de fácil manuseio mas o pH precisa ser observado. Com pH acima de 7,0 e subsequente aquecimento, causou destruiçăo de açúcares e aumento da toxidade do meio.

Segundo LEONARD \& HAJNY (1945), hidróxido de bário e hidróxido de sódio foram de igual qualidade para neutralização e tratamento alcalino dos hidrolisados. 0 aqueci mento de sol uçôs neutras, surtiu o mesmo ef eito que a adição de agentes redutores, isto $e$, aumentou a taxa de fermentação.

Em hidrolisados lignocelulósicos o mals baixo. $\mathrm{pH}$ no qual a levedura cresce satisfatoriamente é $\mathrm{pH} 4,0$. 㕕 medida que se eleva o $\mathrm{pH}$, o crescimento da levedura torna-se mais rápido e aument.a a utilização de açúcar, embora a levedura se torne progressi vamente mais escura CHAJNY, 1981 J.

Segundo PETERSON et alii (1945) as melhores condiçశes para uma fermentaçăo aeróbica em hidrolisados săo 
25.

pH-4,5-5,5; temperatura $25^{\circ}-35^{\circ} \mathrm{C}$, tempo de fermentação: 16 horas para um hidrolisado com $1 \%$ de AT a temperatura de $30^{\circ} \mathrm{C}$; aeração 2 a 4 volumes por minuto; alimentação do mosto $0,5-1 \%$ de AT e adição de nutrientes mantendo o nível acima de $0,3 \%$ de AT.

HARRIS et ali $(1948)$, trabal hando com levedura Torula em hidrolisados 1 ignocelulósicos para obtenção de proteina unicelular, verificaram que ao mesmo tempo em que a levedura consumia os açúcares, também consumia os ácidos orgânicos da sol ução, sendo necessário adicionar áci do sulfúrico para manter o $\mathrm{pH}$ entre 5,0 e 5,5. Os mesmos autores (1948) observaram em testes de soluçöes remanescentes redutoras de hidrolisados que após $75 \%$ do material redutor ter sido utilizados por leveduras, não havia açúcares presentes que respondessem a um teste de osazona, concluindo que $25 \%$ das propriedades redutoras destas solucơs são devidas a não-açúcares.

Foram testados, para levedura crescendo em hidrolisados, várias fonte de nitrogênio: amśnia, fosfato ácido diamoria, sulfato de amônia e uréia. 0 composto que apresentou melhor rendimento em levedura, segundo PETERSON et alii (1945) foi uréia ao nível de 0,00 g por grama de açúcar. Como fontes de fósforo, foram testados fosfato dibásico de potássio, fosfato monobásico de potásio, fosfato diamonio e superfosfato. Os melhores resultados, segundo os mesmos autores, foram com fosfato monobásico de potásio ao nível de 0,05 g de fosfato monobásico por grama de açúcar redutor. 
26.

STAMFORD. (1979) trabalhou com Aspergilius niger crescendo em licor obtido de bagaço de cana, com e sem tratamento para eliminação de furfural. Com substituiçăo pura e simples do meio sintético por licor tratado, houve crescimento do fungo até 0 inivel de substituição de $90 \%$, enguanto no licor não tratado o.crescimento. roi inibido a partir do nível de. $45 \%$ de substituição. A produçăo máxima de biomassa foi obtida quando se usou $100 \%$ de licor tratado em substituiçăo ao meio sintético, na condiçăo nutricional com balanceamento de carbono e nutrientes e pH ajustado para 5, 0. RAMOS et alii (1979) estudaram a levedura candida utilis Y-900 crescendo em meio obtido por hidrólise ácida de bagaço contendo $8 \%$ de açucares rectutores, principalmente xilose e arabinose. Foi feita contagem de células é foi observada a densidade śtica da cultura com e sem adiçăo de extrato de levedura. A velocidade máxima de crescimento especifico foi 0,38/h; $75 \%$ dos açúcares foram consumidos em 34 horas e 0 conteúdo protelco da biomassa foi de $43 \%$

RAMOS (1983) estudou a influéncia do $\mathrm{pH}$ e de algumas bases na fermentaçăo de soluçס̄es obtidas por hidrolise de bagaço com ácido sulfúrico. Estas soluç̧es foram parcialmente ou completamente neutralizadas com hidróxido de cálcio, hidróxido de sódio ou hidróxido de amónio para vários valores de pH. Candida pseudotropicalis cresceu em meio de cultura baseado nessas soluçres. Ruando hidróxido de cálcio, hidróxido de sódio ou hidróxido de potássio, foram usados, o pH aumentou durante a fermentacăo; pH inicial. 
maior que 5,0 deu máxima produção de biomassa em média cerca de 5 g de matéria seca por litro. Tratamento com hidróxido de amónio dirigiu a um pH decrescente durante a fermentaçăo e baixo rendimento de biomassa.

Um estudo sobre melhoramento de produção de leveduras provenientes de xarope hidrolitico a fim de avaliar sua qualidade nutricional foi feito por RAMOS et alii (1983), utilizando Candida pseudotropicalis. o meio de cultura baseado em hidrolisado ácido de bagaço foi neutralizado com hidróxido de cálcio. Em um processo de semibatelada, a taxa de crescimento especifico foi de $0,22 / h$ e $42 \%$ de rendimento sobre os açúcares redutores consumidos. O conteúdo protéico encontrado na biomassa foi de $42 \%$ e $10 \%$ de cinzas. Seu valor nutricional foi comparado com o da levedura Torula em testes com ratos; os resultados mostraram que a levedura Candida poderia substituir a levedura Torula.

\subsection{Levedura}

\subsubsection{Considerações Gerais}

- Os microrganismos, algas, bactérias, fungos e leveduras, são fontes de proteina unicelular, que podem ser utilizadas na alimentaçăo humana e animal. Săo os chamados alimentos não convencionais.

O interesse dos pesquisadores em incluirem os microrganismos na ração animal deve-se ao seu elevado teor protéico, vitaminico e bai xo custo. 
28.

As vantagens dos microrganismos sobre plantas - animais como produtores de proteina, segundo KILBERG (1972) são: possuem um tempo de geração muito curto, por exemplo, as leveduras dobram sua massa num intervalo de tempo de $1-3$ horas; podem ser modificados geneticamente com - objetivo de desenvolver uma qualidade requerida, por exemplo a habilidade de crescer a temperaturas mais altas; 0 conteúdo protéico dos microrganismos é alto; os substratos para a produção dos microrganismos podem ser os localmente disponiveis como residuos liquidos de processamento de frutas, soro de leite, melaço, hidrolisalos de celulose e outros; em culturas continuas, independente de clima, com pouca disponibilidade de espaço e água.

As leveduras podem ser obtidas por inoculação em substratos como melaço, vinhaça, licores sulfiticos e outros, em condiçত̋es adequadas com o objetivo único de se produzir massa celular ou serem obtidas como um subproduto de fermentação. Segundo DESMONTS (1966a) as destilarias de álcool podem produzir os dois tipos de levedura para alimentação humana ou animal: a levedura do género Saccharomyces, recuperada sobre os vinhos da fermentação alcoolica (levedura de recuperaçăo) e a do genero Torula cultívada em vinhaça, em instalaçơs anexas à destilaria clevedura de cultivos. As leveduras do género Saccharomyces, devido as suas condiçశes de recuperação, segundo o mesmo autor, nåo permitem, na maioria dos casos o seu uso direto na al i mentação humana. 
29.

No processo de produção de álcool etilico, as leveduras de recuperaçăo podem ser obtidas de trés maneiras: desvio de parte do leite de levedura, centrifugaçăo da vinháça e aproveitamento do fundo de dornas CD'ARCE \& MACHADO, 1985 \& DE MARTIN, 1987 ).

De acordo com esses mesmos autores, o produto obtido do fundo de dornas é de qualidade inferior áquele obtido do desvio de leite de levedura, principalmente devido à alta concentraçăo de minerais e impurezas cbagacilho, terra, areia, etc e também, à grande variação na sua composiçăo química." A qualidade da levedura de recuperaçăo, por quaisquer das fontes obtidas pode ser melhorada através de lavagens da' levedura com água, o que elimina impurezas, mas podendo causar perdas significativas do material original.

A levedura de recuperaçăo, segundo D'ARCE \& MACHADO (1985) pode ser fornecida como suplemento de raçßes de animais domésticos, no estado "in natura" ou desidratada. No primeiro caso, ela precisa ser fresca porque sofre um processo de deterioraçăo relativamente rápido. A levedura desidratada facilita o transporte, manuseio e possibilita o armazenamento por periodos 1 ongos.

Recentemente, muitos ensalos tem sido realizados com levedura de recuperaçăo a fim de avaliar sua qualidade nutricional para bovinos, sún nos e aves. 
30.

\subsubsection{Composição quimica da levedura}

Vários fatores podem afetar a composição química das leveduras, como natureza do substrato, linhagem, condiçชes de propagação (SALES et alii, 1977) e os tratamentos pos-fermentaçăo (DESMONTS, 1956 a). A natureza do meio de crescimento e o grau de aeraçăo, são oṣ principais fatores que influenciam o conteúdo de carboidratos, protelnas, gorduras e vitaminas (PEPPLER, 1970 ).

FREY (1930), relata para levedura de panificação a seguinte composição: $52,4 \%$ de proteína, $37,1 \%$ de polissacarídeos, $1,7 \%$ de gordura e $8,8 \%$ de cinzas.

Segundo WHITE (1954) as leveduras são constituídas de aproximadamente 44,67\%, de proteínas, acidos nucléicos e bases organicas (purina e pirimidinas na materia seca; 1-2,2\% de fração iiposolúvel: gorduras verdadeiras, esterbides (ergosterol), Iipóides (lecitina); 6-8\% de substâncias inorganicas, encontradas nas cinzas; $1-30 \%$ de glicogênio; celulose acima de 5\%; mananas acima de $4 \%$ e pequenas quantidades de vitaminas, especialmente do grupo $B$, também estão presentes.

HARRISON (1971) apresenta a composiçăo elementar de leveduras, (Tabela 4), com intervalos para as proporçZes dos elementos $\mathrm{CC}, \mathrm{O}, \mathrm{N}, \mathrm{H}$, etc.) encontrados em leveduras comerciais, incluindo levedura de panificação, cervejaria, levedura para alimento humano e anisnal, como mostra intervalos tipicos para os elementos em melaço de cana-de- 
-açúcar e beterraba, como matéria-prima comum obtidas de fonte botanica.

Tabela 4 - Composição elementar de leveduras comerciais e mel aço.

\begin{tabular}{|c|c|c|}
\hline \multirow{2}{*}{ ELEMENTOS } & LEVEDURA & MELAÇO \\
\hline & (g/100g matéria seca) & (grloog matéria seca) \\
\hline C. & $45-47$ & $39-41$ \\
\hline$H$ & $6,0-6,5$ & $6,3-6,8$ \\
\hline 0 & $31-32$ & $47-50$ \\
\hline$N$ & $7,5-9,0$ & $0,1-2,8$ \\
\hline$k$ & $0,9-3,5$ & $0,8-5,2$ \\
\hline$P$ & $1,1-2,0$ & $0,01-0,9$ \\
\hline$S$ & $0,3-0,5$ & $0,15-0,2$ \\
\hline $\mathrm{Mg}$ & $0,15-0,5$ & $0,007-0,75$ \\
\hline C.a & $0,04-0,9$ & $0,018-1,2$ \\
\hline $\mathrm{Na}$ & $0,02-0,2$ & $0,82-1,4$ \\
\hline $\mathrm{Zn}$ & $0,004-0,13$ & $0,0006-0,013$ \\
\hline $\mathrm{Fe}$ & $0,003-0,1$ & $0,01-0,021$ \\
\hline Cus & $0,002-0,012$ & $0,0001-0,006$ \\
\hline Mn & $0,0004-0,0035$ & $0,001-0,004$ \\
\hline Co & 0,0005 & $0,00004-0,0001$ \\
\hline Mo & $0,000005-0,000009$ & $0,000009-0,000028$ \\
\hline C.1 & $0,004-0,1$ & 1,3 \\
\hline$I$ & $0,00005-0,0004$ & - \\
\hline $\mathrm{Pb}$ & $0,0001-0,0007$ & 0,0006 \\
\hline As & 0,00001 & - \\
\hline $\mathrm{Si}$ & - & 0,028 \\
\hline $\mathrm{Sr}$ & - & 0,005 \\
\hline B & - & $0,0002-0,0004$ \\
\hline
\end{tabular}

Fonte: HARRISON, (1971). 
32.

PEPPLER (1970) relata que metade do peso seco das leveduras é proteina bruta $C N \times 6,25)$ com $80 \%$ de aminoácidos, $12 \%$ de ácidos nucléicos e 8\% de amónia; cerca de $7 \%$ do nitrogenio total ocorre na forma de aminoácidos livres. A presença de grande quantidade de purinas e pirimidinas (constituintes dos ácidos nucléicos) baixa o teor de proteinas para $40 \%$ de proteina verdadeira sobre o peso seco da levedura. O nitrogenio ocorre em menor quantidade nos constituintes: glutationa, lecitina, ácido adelínico, vitaminas e enzimas.

As proteinas de leveduras são bem balanceadas em aminoácidos quando comparadas com as proteinas do ovo, mas apresentam deficiencia em aminoácidos sulfurados CKILBERG, 1972 e VANANUVAT \& KINSELLA, 1975). As leveduras são deficientes em metionina, porém possuem al to teor em lisina, aminoácido que em trigo e na maioria dos cereais é muito baixo; por esse motivo a levedura é indicada para suplementação de dietas à base de cereais CDESMONTS, 1966b; PEPPLER, 1970; KILBERG; 1972; FLANNERY, 1975; VANANUVAT \& KINSELLA, 1975 e SALES et ali 19773 . Quando a levedura fo suplement.ada com metionina a eficiência de utilização protéica chega bem. perto daquela da caseina CPEPPLER, 1970 e SALES et alii, 19773 .

A Tabela 5, mostra a composição em ami noácidos essenciais de algumas leveduras comerciais (PEPPLER, 1970 ). 
Tabela 5 - Composição em aminoácidos essenciais de leveduras alimentares comerciais.

\begin{tabular}{lccc}
\hline \multirow{2}{*}{ AMINOACIDO } & \multicolumn{1}{c}{ TEOR NA LEVEDURA $(\mathrm{g} / 16 \mathrm{~g} N$} & \\
\hline & A & B & C \\
\hline Lisina & 8,2 & 6,7 & 9,7 \\
Valina & 5,5 & 6,3 & 5,9 \\
Leucina & 7,9 & 7,0 & 7,7 \\
Isoleucina & 5,5 & 5,3 & 7,3 \\
Treonina & 4,8 & 5,5 & 7,0 \\
Metionina & 2,5 & 1,2 & 3,5 \\
Fenililanina & 4,5 & 4,3 & 5,6 \\
Triptofano & 1,2 & 1,2 & 1,7 \\
Cistina & 1,6 & 0,7 & 1,2 \\
Histidina & 4,0 & 1,9 & 3,6 \\
Tirosina & 5,0 & 3,3 & 4,5 \\
Arginina & 5,0 & 5,4 & 4,3 \\
\hline
\end{tabular}

Fonte: PEPPLER, (1970).

A - Saccharomyces cerevisiae de melaço.

B - Candida utilis de licor sulfitico.

C. - Levedura de panificação.

A levedura e uma das fontes naj.s ricas em vitaminas do complexo B CLIMA, 1966; PEPPLER, 1970; KILBERG, 1972 e SALES, et alii 1977). As vitaminas do complexo B, com altos teores de niacina e riboflavina (HSU, 1961 ) ocorrem em leveduras principalmente como componentes de enzimas e coenzi mas (PEPPLER, 1970 ) 
34.

Segundo LIMA (1966), o teor de cinzas é relativamente al to em leveduras, dependendo da espécie, raça - das condiç̧̋es de cultivo, devendo-se ainda considerar a possibilidade de uma impurificaçăo mineral extracelular, no caso de leveduras forrageiras a partir de rejeitos ricos em suspensão coloidal, como ocorre nas vinhaças de destilarias e mostos de melaço de cana.

As leveduras comerciais apresentam $6-8 \%$ de cinzas sobre a matéria seca. A maioria das cinzas é constituida por potássio e fósforo, com menor quantidade de cálcio, magnésio e enxofré CPEPPLER, 19703.

DESMONTS (1966b) relata que a relaçăo Pria em levedura é elevada, porém MIYADA \& LAVORENTI (1979) e FIALHO et alii (1983) trabalhando com levedura Saccharomyces cerevisiae de destilaria de álcool de cana-de-açúcar obtiveram respectivamente a relaçăo $\mathrm{Ca} / \mathrm{P}$ de 1,98 e 1,78, consideradas adequadas para alimentaçăo de suínos.

Os carboidratos constituem $22-34 \%$ do peso seco das leveduras com aproximadamnte $32 \%$ de trealose, $27 \%$ de glucanas, $21 \%$ de mananas $12 \%$ de glicogennio. As mananas glucanas são maiores componentes das paredes da célula de. levedura, associadas com protelnas e lipideos CPEPPLER, 19703.

O teor em lipideos nas leveduras está ao redor de $2 \%$ (HSU, 1961). Quando num meio de crescimento fortemente aerado existe quantidade de fósforo, com escassez de nitrogenio, para limitar produça de protelna, o teor em 
35.

lipideos se eleva na levedura CHSU, 1961; PYKE, 1964 e KILBERG, 1972), podendo chegar a $60 \%$ do peso seco da levedura para. "fat yeasts" CHSU, 1961 e KILBERG, 1972), adquirindo cor marrom (HSU, 19601 ).

Os principais componentes dos lipideos de leveduras são: triglicerideos, lecitina e ergosterol. Há predominância dos triglicerldeos dos ácidos oléico e palmitico (PEPPLER, 1970 e HSU, 1961). O teor em ergosterol e extremamente baixo em torno de $0,1 \%$, exceto para o genero Saccharomyces, que segundo DULANEY, et alii (1954) em um experimento com melaço e infusão de milho, para verificà a habilidade de sessenta espécies de leveduras em produzir ergosterol encontrou rendimentos de $7-10 \%$ de ergosterol para Saccharomyces cerevisiae. O ergosterol tem importancia na composição da levedura pelo fato de se converter em calciferol (vitamina $\mathrm{D}_{2}$, por irradiação com raios ultravioletas (HSU, 1961 e PEPPLER, 1970 ).

\subsection{Valor nutritivo da levedura}

Até o presente momento somente leveduras. obtidas a partir de hidratos de carbono tem sido usadas na alimentação humana, no preparo de produtos dietéticos, sopas, biscoitos, produtos de carne, etc CSALES el alii, 19773. Pelas suas propriedades fisicas e quimicas, as leveduras são usadas como aditivos de alimentos. Como um agente antioxidante, a levedura é utilizada na preservaçăo 
36.

de alimentos, como por exemplo em cremes. A levedura em pó adicionada a pães e bolos preserva a umidade dos produtos permanecendo frescos por mais tempo. Em bolachas, quando adicionada, melhora a fragância e fragilidade (HSU, 1961 ).

As leveduras como um alimento rico em protelnas, com elevado teor de lisina, triptofano e vitaminas CPEPPLER, 1970 Jem sido recomendadas para enriquecimento de raçăes à base de cereais (LIMA, 1966$).$

MATTOS et aiii (1983) realizaram um ensaio biológico com ratos para avaliar a qualidade da proteina de levedura. Os ratós foram alimentados com levedura seca obtida de fundo de dorna de fermentaçă alcoólica, em dietas isoprotéicas e isocalóricas, com niveis de substituiçă da caseina por levedura iguais a $0 ; 50$ e $100 \%$, nos tratamentos $A, B \in C . C A=100 \%$ caseina, $B=50 \%$ caseina e 50\% levedura seca, $C=100 \%$ leveduras. os resultados para taxa de eficiencia protéca para proteina brutá foram: 0,71;0,59; 0,47 e para proteina verdadeira: 0,71;0,73;0,74. A taxa de eficiencia protelca para proteina verdadeira nå foi diferente nos trés tratamentos. Os resultados parecem indicar, segundo os autores, que o menor desempenho dos animais que receberam o tratamento $c$, pode ser devido aos teores elevados de nitrogênio năo protéico da levedura quando comparados com a caseína.

- maior número de pesquisas com a levedura seca de destilarias de álcool tem sido desenvolvido com suinos. MI YADA (1978), estudou o efeito da adição de vários 
37 .

niveis de levedura seca obtida de destilaria de álcool de cana-de-açúcar em raçơes de sulnos em crescimento e acabamento sobre o desempenho e qualidade da carcaça dos animais. A qualidade da carcaça foi melhorada com a elevação dos niveis da levedura seca, pois além de uma tendencia em diminuir a espessura do toicinho, houve uma redução linear da relação gordura carne e um aumento linear da percentagem de pernil. Os resultados indicaram a possibilidade de uso da levedura seca como fonte de protelnas para suinos em crescimento e acabamento, pelo menos até o nivel de $21 \%$ da ração. LIMA (1983), usando os mesmos níveis de levedura seca co; 7; 14;.21\% em substituiçăo ao milho e farelo de soja na alimentação de matrizes suinas em gestação e lactaçăo, concluiu que existe a possibilidade do emprego de levedura seca como fonte de proteinas para as matrizes suínas, pelo menos até o nivel de $21 \%$.

De acordo com BERTO (1985), o uso de levedura seca até o nível de $45 \%$ de substituição à protel na do milho e farelo de soja nas raçôes de leitß̧es em recria é possivel e está na dependéncia da disponibilidade e do custo do produto.

MIYADA (1978) e BERTO (1985) observaram um maior consumo diário de ração e uma pior conversão alimentar (consumo de ração/ganho de peso) dos animais com o aumento da levedura seca na ração. A hipótese levantada é de que tais resultados tinham sido uma consequéncia do baixo nivel energético das raç̧es contendo a levedura CMIYADA, 1978; 
MIYADA \& LAYORENTI, 1979 \& BERTO, 1985). MOREIRA (1984), trabal hando com o mesmo tipo de levedura, mas com raçōes isocalóricas, não encontrou diferenças estatisticas significativas no desempenho de suínos em crescimento e termi naçăo.

KRONKA et alii (1987) em experimento com suinos verificaram os efeitos da levedura seca e do farelo de arroz no desempenho e caracteristicas de carcaças de suínos, concluíndo que o farelo de arroz e a levedura seca podem, substituir em $25 \%$ as fontes energéticas e protéicas, respectivamente.

MACHADO, (1983) substituindo o farelo de algodăo do concentrado por levedura seca, obtida do desvio de parte de leite de levedura, em experimento com vacas da raça Holandesa em inicio de lactaçăo concluiu que a substituiçăo de $100 \%$ do fárelo de algodão por levedura seca resultou em maior eficiencia digestiva, maior produçăo de protelna do leite, sem efeitos adverso na composição do leite e nos parametros sanguíneos. A proteina do farelo de algodåo pode ser substiuida pela protel na da levedura, em dietas de ruminantes, com vantagens (MACHADO et ai $i i, 1983$ ).

Segundo MATTOS et alii (1987); os resultados com vacas em lactaçăo ulceradas sugerem que a levedura é un substrato adequado para manter a fermentaçăo no $r$ umen proporcionando um aumento de microrganismos alguns metabolitos importantes para a sintese do leite. 
39.

CAMPOS NETO et alii (1987) desenvolveram um trabalho com cabras leiteiras a fim de avaliar o valor alimentar do bagaço de cana hidrolisado e da levedura seca. na produção de leite. Os autores concluíram que o bagaço de cana hidrolisado e a levedurà seca poderăo ser utilizados na alimentação suplementar de caprinos, principalmente no perílodo seco.

HALDROUP \& HAZEN (1975) em experimento utilizando 0; 2,$5 ; 5 ; 10$ e 15\% de levedura em adição a rações de mistura de farelo de milho e farelo de soja, isoproteicas e isocalóricas, verificaram que a produçăo de ovos $e$ o desempenho da aves não for am prejudicadas pela inclusão cia levedura nos niveis citado, indicando que a levedura desenvolvida em alcanos de alta pureza é adequada para uso em dietas nutricional mente balanceadas para aves poedeiras.

MOURA et ali.i (1982) observaram que em raçaes para frangos de corte constitúdas por farinha de peixe, farelo de soja e carne, a substituiçăo da farinha de peixe pela levedura Saccharomyces cerevisiae de alccol de cana-de-açúcar, praticamente não afetou o desenvolvimento dos animais, o mesmo não ocorrendo com a substituição da carne, assim como da carne e do peixe concomitantemente.

PEZZATO et alii (1982) conduziram um escperimento com dietas isocalóricas e isoprotéicas de milho nais soja com suplementos vitaminicos e minerais para frangos de corte, com substituiçăo do milho mais soja por 0; 10; 20 e $30 \%$ de levedura seca. O melhor desempenho das aves verifi- 
40.

cou-se com a inclusão de $10 \%$ de levedura seca. Os autores concluiram que até "níveis de $20 \%$ da levedura em raçōes para aves a adição de levedura constituiu-se numa excelente alternativa economizadora de milho e soja para raçōes de frango de corte.

TAMBURO et ali $(1982)$ em trabalho realizado com frangos de corte e nas mesmas condições do experimento anterior, observaram que à medida que se eleva o.teor de levedura seca obtida durante a fabricaçăo de álcool de cana-de-açúcar na ração, há um incremento de umidade das excretas.

PEZZATO ( 1985 ) concluiu dos trabalhos realizados com levedura cultivada em melaço de cana-de-açúcar, na alimentação de aves, que os niveis mais promissores de substituição de soja e milho pela levedura foram na faixa de 10-15\% da ração e que em níveis superiores as fezes das aves tornam-se pegajosas.

\subsubsection{Efeito tóxico da levedura}

Devido ao elevado tieor de ácidos nucléicos em leveduras, 6-8\% em Saccharomyces cerevisiae, 5,5\% para Toruia (VILLALON \& TAGLE, 1973 ) muitos pesquisadores tom se preocupado com os posșiveis efeitos deleterios dos produtos de degradação das purinas e pirimidiras, bases nitrogenadas

provenientes dos ácidos nucléicos. As pirimidinas se degradam sucessivamente até acetil-S-COA e succinil-S-CoA. 
Parte do nitrogenio das pirimidinas é excretada na urina na forma de $\beta$-alanina, carbanil-ß-alanina e ácido $\beta$-aminoisobutirico (SLAGLE \& ZIMMERMAN, 1979) e provavelmente na forma. de amónia.

O maior problema poderá surgir do metabolismo das purinas, que no homem o produto final é o ácido úrico. Segundo KILBERG (1972), o homem ingerindo alta quantidade de ácidos nucléicos na dieta fica sujeito a alta concentração de ácido úrico no plasma e aumento de excreção de ácido úrico na urina, proveniente da degradação das purinas. Sendo - ácido úrico pouco solúvel, um aumento de sua concentraçăo no plasma pode resultar em precipitaçăo de uratos nos tecidos e nas articulações. Algumas pedras podem ser formadas nos rins e bexiga.

Nas aves, no homem, nos macacos superiores, no cão dal maciano, a degradaçăo das purinas (adenina e guanjna) termina na etapa do ácido urico. Nos demais mamiferos o catabolismo das purinas prossegue até alantoina por ação da enzima uricase (KILBERG, 1972 e PEZZATO, 1985). Os suínos tem a capacidade de metabolizar o ácido úrico em alantoina CSLAGLE \& ZIMMERMAN, 1979 PEZZATO, 1985) por ação da uricase, mas por deficiencia de guanase, os produtos finais do metabolismo das purinas são a guanina e a alantoina, não depositando ácido úrico (uratos) nas articulaçóes mas podendo apresentar "gota" em consequencia de deposiçőes de guanina nas mesmas regiöes do corpo (PEZZATO, 1985). 
42.

MATTOS et alii (1983) não constataram alteraçơes no fígado, rins, baço e intestinos de ratos alimentados com levedura seca obtida de fundo de dorna, quando este produto substituiu a caseina na raçăo aos niveis de 0; 50 e $100 \%$ da proteina bruta.

MENTEM et alii (1984) em estudos realizados com porcas em gestaçăo e lactação, alimentadas com levedura seca, observaram uma variaçăo inconsistente nos níveis de ácido úrico no sangue, indicando que as purinas ou não foram absorvidas ou, em caso positivo foram metabolizadas a outro produto, não havendo acúmulo de ácido úrico no sangue.

PEZZATO (1985) concluiu que até o nivel de substituiçăo de 10-15\% de soja ou milho por levedura seca, na ração de aves, năo afeta a consistencia das fezes das mesmas.

FAZANO (1986) com objetivo de avaliar a qualidade da proteina de levedura seca obtida durante a fabricação de álcoiol de cana-de-açúcar, comparada com o farelo de soja em alimentaçăo de coelhos em crescimento, aos níveis de 8 e $12 \%$ de protel na total, não observou qualquer anormalidade nos animais submetidos a esses tratamentos.

De acordo cóm MATTOS et alii (1987) a administração de leveduras para vacas em lactaçăo em quantidades até $4 \mathrm{~kg} /$ dia não causou efeitos patológicos ou alteraçăo fisiológica a esses animais. 
43.

\section{MATERIAL E METODOS}

\subsection{Matéria-Prima}

A matéria-prima utilizada neste trabalho foi bagaço de cana-de-açúcar, coletado na Usina Modelo - Piracicaba - SP, não tendo sido possível detectar a variedade de cana-de-açúcar.

3.2. Substrato para Fermentação

No mesmo dia da coleta de bagaço, foram preparados o extrato e o licor de bagaço nos laboratórios do Departamento de Tecnologia Rural e do Departamento de Ciancias Florestais, da ESALQ.

\subsubsection{Extrato de bagaço}

Procedeu-se a extração do caldo residual do bagaço pelo método do digestor a frio, de acordo com C.OOPERATIVA DOS PRODUTORES DE C.ANA, ACUUCAR E ALC.OOL DO ESTADO DE ST̃ PAULO LTDA, COPERSUCAR, (1978). 


\title{
3.2.2. Licor de bagaço
}

\begin{abstract}
O licor de bagaço de cana-de-açúcar foi obtido através de autóclavagem do bagaço úmido misturado com água na proporção de $1: 10$ (Peso secorvolume) à temperatura de $170^{\circ} \mathrm{C}$ por $30 \mathrm{minutos,} \mathrm{em} \mathrm{um} \mathrm{digestor} \mathrm{rotativo} \mathrm{com} \mathrm{capacidade}$ para 20 litros, segundo STAMFORD (1979).
\end{abstract}

\section{3. Determinações Analiticas}

- Umidade \% bagaço, segundo PAYNE (1968);

- Brix do extrato e do licor por refratometria, "segundo PAYNE. (1968);

- Açúcar total do extrato e do licor e açúcar residual no vinho delevurado foram determinados pelo método de Somogyi e Nelson, descritos por PASSOS et aii i (1960), com prévia inversão da sacarose do extrato, descrito por AMORIM et ali $i$ (1979) modificado. Açúcar residual, com prévia desproteinjzacão das amostras, segundo VILLELA et alii (1973);

- pH: Determinado por potenciometria;

- Nitrogênio: Pelo método Micro-Kjeldahl, descrito por MEEKER \& WAGNER (1933);

- Fósforo: Pelo método de GOMORI (1942);

- Cálcio e magnésio: Pelo método complexométrico do EDTA, descrito por OLIVEIRA et alii (1974);

- Potássio: Por fotometria de chama, segundo GLORIA \& SANTA ANA (1975); 
45.

A composição do extrato e do licor em umidade \% bagaço, Brix, açúcares totais (AT), AT\% bagaço e o pH do extrato e do licor são apresentados na Tabela 6. A composiçăo do extrato e do licor em $N$, P, K, Ca e Mg, na Tabela 7.

- Acidez: A acidez, expressa em ácido acético, do extrato do digestor, do licor $e$ do vinho delevurado foi determinada através de titulação com uma solução de hidróxido de sódio o, OZN em potenciómet.ro até pH 7,0;

- Açúcares do iicor: No licor de bagaço foi realizada análise dos açúcares residuais mais os provenientes da pré-hidrólise do bagaço por cromalografia líquida de alta pressão (HPCL). A composição do licor nos açúcares hidrolisados se encontram na Tabela 8;

- Furfural: Por HPCl. Para eliminação de furfural, um inibidor de fermentaçăo, o licor foi neutralizado com uma solução de hidroxido de sódio $1 \mathrm{~N}$ e a seguir evaporado até seu volume se reduzir à metade. Em seguida foi adicionada água destilada ao licor evaporado, voltando ao seu volume inicial CSTAMFORD, 19793. O teor de furfural existente na amostra de licor original era 315 ppm e $36^{\circ}$ ppm no licor tratado;

- Etanol: 1. Determinação por densimetria, segundo AM()RIN et alii 1979), realizada no final de todos os ensaios de fermentação; 2. Determinação pelo método dis 
46.

oxidação do etanol pelo dicromato de potássio CJOSLYN, 1970), modificado por HORII \& STUPIELLO (1970); método utilizado no Ensaio IV, para acompanhamento cinético da produção de etanol;

- Massa seca de células: 1. Para inóculo. Pesagem de três amostras de uma grama de fermento prensado, secagem em estufa a $105^{\circ} \mathrm{C}$ até peso constante $(10-16 \mathrm{~h})$, segundo HARRISON (1971). 2. Após fermentação. o sedimento da centrifugação era suspenso em água destilada e novamente centrifugado, desprezando-se o sobrenadánte. A seguir, era filtrado em membrana "millipore", som diámetro de poro igual a $1,2 \mu$, conforme descrito por BUENO NETTO (1982) e a massa seca de células era obti da após secagem a $105^{\circ} \mathrm{C}$ até peso constante CHARRISON, $1971)$;

Tabela 6 - Umidade \% bagaço, Brix, pH, açúcar total (AT) e AT\% bagaço do extrato do digestor e do licor.

\begin{tabular}{lrc}
\hline ELEMENTOS & EXTRATO & LICOR \\
\hline Brix & 0,50 & 3,00 \\
pH & 4,00 & 5,30 \\
AT $(m g / 100 \mathrm{ml})$ & 310,00 & 1720 \\
AT $(\%$ bagaço) & 3,20 & 7,79 \\
\hline Unidade $\%$ bagaço & 52,44 & \\
\hline
\end{tabular}


Tabela 7 - Teores de nutrientes minerais no extrato $e$ no licor de bagaço.

\begin{tabular}{ccc}
\hline ELEMENTOS & $\begin{array}{c}\text { EXTRATO } \\
\text { (PPM) }\end{array}$ & $\begin{array}{c}\text { LICOR } \\
\text { (PPM) }\end{array}$ \\
\hline$N$ & 19,36 & 79,80 \\
$P$ & 3,41 & 20,05 \\
$K$ & 62,50 & 177,50 \\
Ca & 49,28 & 140,80 \\
Mg & - & - \\
\hline
\end{tabular}

Tabela 8 - Açúcares do 1 icor de bagaço.

\begin{tabular}{lc}
\hline Açúcares & TEOR \% \\
\hline melibiose & ANTES DA FERMENTAÇÃO \\
glucose & 0,05 \\
xilose & 0,17 \\
xilitol & 0,31 \\
arabinose & - \\
outros sacarideos & 0,09 \\
\hline
\end{tabular}

3. 4. Inóculo

O microrganismo utilizado em todos os ensaios foi Saccharomyces cerevisiae, conhecido como levedura de panificaçăo, obtido na forma de fermento prensado comercial. A quantidade de fermento utilizada na fermentação foi de umá grama de fermento para cada $100 \mathrm{ml}$ de substrato. 
48.

O preparo do insculo consistia na diluição de uma grama de fermento prensado em $10 \mathrm{ml}$ de água destilada, o qual era transferido ao frasco de Erlenmeyer usado na fermentação, adicionando-se mais $10 \mathrm{ml}$ de água destilada, utilizados na lavagem do béquer.

\subsection{Suplementaçăo de Sais dos Substratos}

A quantidade dos nutrientes foi calculada a partir da composiça elementar de leveduras e rendimento em leveduras por $100 \mathrm{~g}$ de glucose (HARRISON, 1971), considerando a composição do extrato e do licor em açúcares e minerais.

Os meios foram suplementados com:

\section{Para Licor:}

- 786 ppm de N na forma de uréia;

- 172 ppm de $\mathrm{P}$ na forma de fosfato monobásico de potássio.

\section{Para Extrato:}

- 131 ppm de $N$ na forma de uréia;

- 30 ppm de P na forma de fosfato monobásico de potássio.

\subsection{Descrição dos Equipamentos}

As fermentaçסes foram realizadas em frascos de Erlenmeyer de $500 \mathrm{ml}$. Esses fermentadores eram colocados em banho-maria dotado de agitador com temperatura controlada $\epsilon$ sob agitação de 200-2Zo movimentos por minuto. 
49.

Através de trompa de vácuo o ar atmosférico borbulhava em um frasco de Erlenmeyer com ácido sulfúrico e em seguida pasșava por água destilada em outro frasco, para evitar que o ácido sulfúrico fosse arrastado pelo ar aos frascos de Erlenmeyer seguintes de fermentação.

Os frascos de Erlenmeyer foram tamponados com rolhas de borracha com duas perfuraçōes onde foram adaptados dois tubos de vidro, um que mergulhava no substrato e outro situado acima do nivel do substrato que retirava o ar, através de vácuo, levando-o para o fermentador seguinte.

\subsection{Descrição de um Ensaio Tfpico}

Os frascos de Erlenmeyer usados na fermentaça com $100 \mathrm{ml}$ de substrato juntamente com as rolhas de borracha e conexốes eram esterilizados a $120^{\circ} \mathrm{C}, 1,0$ atmosfera de pressão, por 10 minutos. Após esse tratamento o inóculo era introduzido nos frascos e homogeinizados. Aos substratos licor eram adicionadas 3 gotas de octanol como antiespumante.

Os frascos eram colocados em banho maria, a temperatura de $35^{\circ} \mathrm{C}$, agitados e interligados para efeito de. aeraçăo dos substratos. Com a introdução de ar e agitaçăo dos frascos marcava-se o inscio da fermentaçăo.

Após 24 horas os frascos eram retirados do agitador e procedia-se à medida do volume final do vinto e as análises pós-fermentaçăo esquematizadas na Figura 2 . 
50.

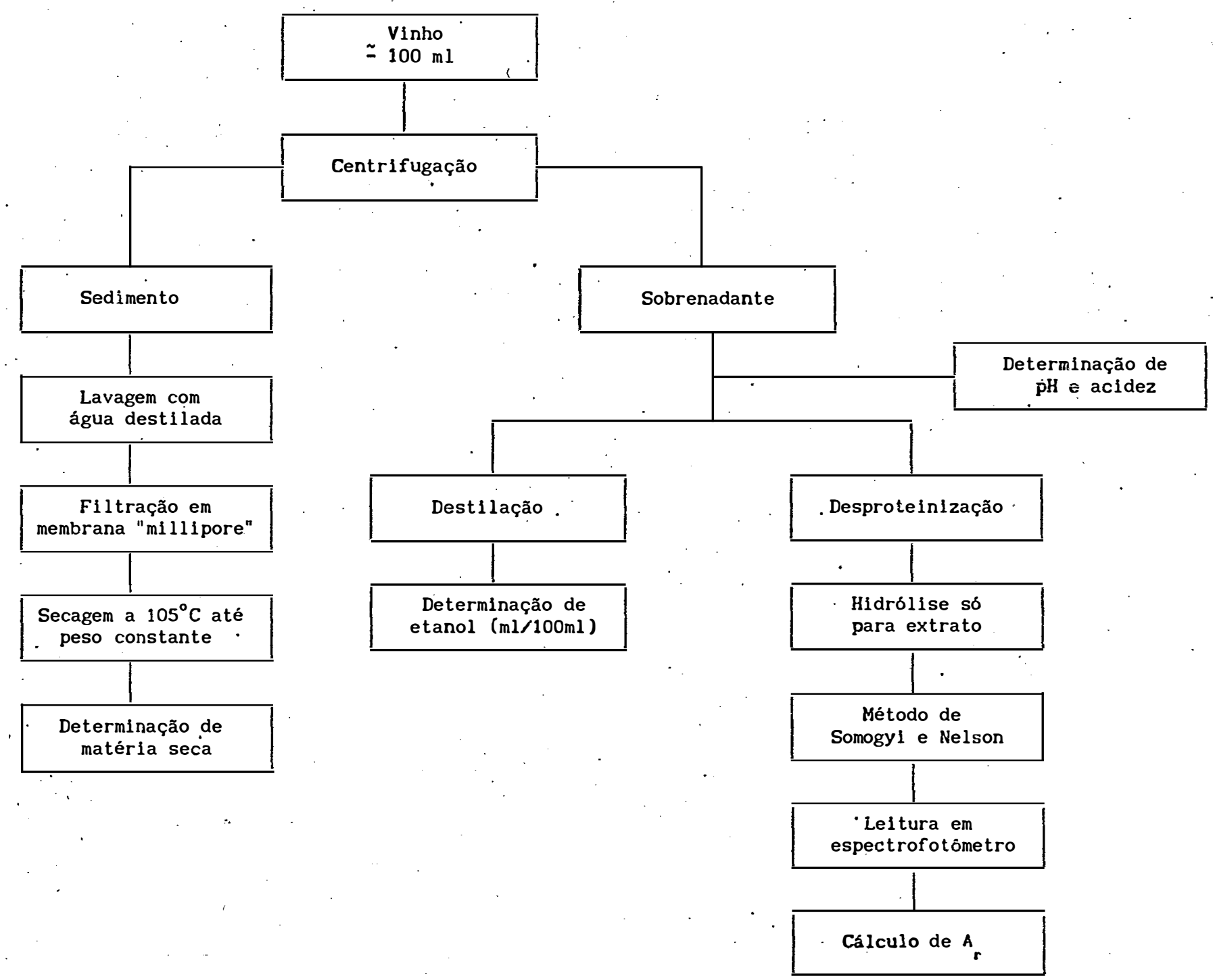

\footnotetext{
Figura 2 - Esquema das análises realizadas em um ensaio tipico.
} 
51.

Antes de cada fermentação era medido o $\mathrm{pH}$ e feitas determinaçôes de acidez, expressa em ácido acético, do extratio e do 1 icor.

Terminado o período de fermentação (24 horas) e medido o volume do vinho, este era centrifugado a $3000 \mathrm{rpm}$ (800 g) por $10 \mathrm{~min}$, obtendo-se dois produtos: sobrenadante e sedi mento.

No sobrenadante ou vinho delevurado, eram determinados $\mathrm{pH}$ e acidez, expressa em ácido acético, açúcares residuais e etanol. No sedimento da centrifugaçăo do vinho era determinada massa seca de celulas conforme descrito em determinaçôes analisticas.

Cada ensaio era constituido de três repetiçaes para licor e três repetiçôs para extrato.

\subsection{Variação do Ensaio Típico}

Foram realizados nove ensaios de fermentação. - primeiro ensaio foi. realizado sem aeraça e os oito restantes com aeração.

A medida do etanol no Ensaio 4 foi feita pelo método de oxidação do etanol pelo dicromato de potássio a cada quatro horas e no final da fermentação.

A partir do Ensaio $\mathbf{S}$ fói aumentada a aeração e os frascos de fermentaçăo nåo mais se interligavam.

A partir do Ensaio 6 foi feita a suplemetaçăo de sais dos substratos com uréia e fosfato monobásico de potássio. 
52.

\subsection{Cálculo dos Rendimentos}

3.9.1. Rendimento do substrato $\left(n_{s}\right)$

O rendimento em cellulas de leveduras em rela̧ão ao substrato expressa a massa de levedura produzida por $100 \mathrm{miligramas}$ de açúcar total do substrato.

$$
\begin{aligned}
& \eta_{s}=\frac{M_{x}}{1720} \times 100 \text { (1icor) } \\
& n_{s}=\frac{M_{x}}{310} \times 100 \text { (extrato) }
\end{aligned}
$$

3.9.2. Rendimento biológico (n)

Convencionou-se chamar Rendimento biologico, a massa celular produzida por 100 miligramas de açúcar total consumidos durante a fermentaçăo.

$$
\eta=\frac{M_{x}}{A_{c}} \times 100
$$

\section{3.io. Cálculo das Eficiências}

3.10.1. Eficiência do processo biologico (E)

$100 \mathrm{mg} \mathrm{AT} \longrightarrow 47,5 \mathrm{mg}$ massa seca de celulas

$A_{c} \longrightarrow x$ 
53.

$$
\begin{aligned}
& \text { onde: } \\
& x=\text { massa seca de celulas esperada. } \\
& \quad x=\frac{47,5 \times A_{c}}{100} \\
& 0,475 A_{c} \longrightarrow 100 \% \text { Eficiencia } \\
& \qquad=\frac{M_{x} \longrightarrow \varepsilon}{0,475 A_{c}} \times 100
\end{aligned}
$$

3.10.2. Eficiência do processo em relação ao açúcar total do substrato $\left(\varepsilon_{s}\right)$

$$
\begin{aligned}
& \varepsilon_{s}=\frac{M_{x}}{147} \times 100 \text { (exirato) } \\
& \varepsilon_{s}=\frac{M_{x}}{817} \times 100 \text { (1icor) }
\end{aligned}
$$

3.11. Cálculo da Razão de Crescimento Celular ( $R_{x}$ )

$$
R_{x}=\frac{M_{x}}{M_{x 0}} \times 100
$$


54.

\section{RESULTADOS E DISCUSSAO}

\subsection{Pré-Hidrólise}

Pela metodologia empregada do digestor a frio para obtenção do extrato de bagaço, obteve-se um substrato com 0,31\% de açúcar total (AT). Esses açúcares representam os açúcares do caldo residual da cana-de-açúcar processada.

No preparo do licor pela autoclavagem do bagaço úmido, obteve-se no licor 1,72\% de açúcar total, correspondentes aos açúcares residuais do bagaço mais os açúcares hidrolisados (Tabelas 6 e 8). Como as diluiçôes for am diferentes no extrato de bagaço e pré-hidrolisado de bagaço, por força da metodologia empregada, os dois substratos, extrato e licor, provenientes da mesma remessa de bagaço, puderam ser comparados em relação ao teor de açúcar, transformando os açúcares em ambas soluçăes em açúcar porcento bagaço. Obteve-se para extrato, $3,26 \mathrm{~kg}$ de AT por $100 \mathrm{~kg}$ de bagaco e no licor $7,79 \mathrm{~kg}$ de. AT por $100 \mathrm{~kg}$ de bagaço (Tabela (5). Desses resultados pode-se constatar que houve hidrólise da hemicelulose do bagaço com aumento no teor de açúcares no 1 icor de $138,95 \%$. 
55.

Com a pré-hidrólise do bagaço houve desdobramento de hemicelulose em melibiose, glucose, xilose e arabinose, aumentando o teor de açúcares no licor (Tabela 8), onde xilose e o principal componente do hidrolisado, de acordo com DU TOIT et alii (1984), seguido de glucose, arabinose e melibiose. A maior quantidade de glucose, relacionada aos outros componentes, segundo o mesmo autor, pode ser proveniente da hidrólise de substancias como amido, de celulose amorfa e mesmo sacarose presentes no bagaço.

Pela proporção dos monossacarídeos liberados na hidrolise a vapor e porque a hemicelulose A chemicelulose precipitada por ácidoss é mais facilmerite hidrolisável, supre-se que esta tenha sido a hidrolisada por esse processo.

\subsection{Ensaios}

Os resultados obtidos nos ensaios realizados neste trabalho encontram-se nas Tabelas 9 a 23.

Para cada grupo de ensaios são esperificadas as condiçశes experimentais: umidade do fermento, matéria seca de fermento inoculado, volume de substrato utilizadoe açúcar total do extrato e do licor.

STo apresentados para cada grupo de ensaios os valores encontrados para massa seca de celulas apos fermentação, massa seca de cellulas obtidas na fermentação, açúcares residual e consumido, valores para razå de crescimento celular, rendimentos e eficiencias em relação ao açucar 
56.

total e ao açúcar consumido, bem como $\mathrm{pH}$ e acidez acética antes e após fermentaçăo.

os ensaios serão analisados separadamente, (Ensaio I), ou em conjunto, CEnsaios II a V e VI a IXS, para as mesmas condiçбes experimentais.

\subsubsection{Ensaio I (sem aeraçăo)}

As condiços experimentais do Ensaio I se encontram na Tabela 9.

Tabela 9 - Condiçбes experimentais do Ensaio I (sem aeraçăo).

\begin{tabular}{lc}
\hline VARI AVEIS & ENSAIO I \\
\hline$U_{x}(\%)$ & 330 \\
$M_{x 0}(\mathrm{mg} / 100 \mathrm{ml})$ & 100 \\
$V(\mathrm{ml})$ & 310 \\
AT $_{1}(\mathrm{mg} / 100 \mathrm{ml})$ & 1720 \\
AT $_{2}(\mathrm{mg} / 100 \mathrm{ml})$ & \\
\hline
\end{tabular}

- Ensaio I foi realizado sem aeraçăo e obteve-se rendimento médio em células de levedura em relafão ao açúcar total $\left(n_{s}\right)$, crescendo no 1 icor igual a $3,13 \%$ e $18,66 \%$ para as celulas crescendo no extrato, com porcentagem de açúcar consumido igual a $55,72 \%$ no licor e $39,54 \%$ no extrato CTabelas 10 e 11). Esse crescimento provavelmente se deve ao 
57.

ar contido no frasco de Erlenmeyer e ao ar introduzido pela agitação e esta agitação pode não ter dado condiçฉ̄es de atingir os 2 a 4 volumes de ar por volume de mosto por minuto, encontrados por PETERSON et ai $i$ (1945) com a melhor condução para fermentação aeróbica em hidrolisados, ou esse crescimento se deve ao consumo de álcool que possa ter sido produzido, mas não detectado no final da fermentação. o rendimento em células de levedura no extrato, superior ao encontrado no licor, talvez se deva ao fato de que a agitação fosse suficiente para crescimento da levedura em função da baixa concentração de açúcar no extrato e ao fator inibitorio de fermentaçăo no licor representado pela mistura de pentoses e hexoses, segundo FANTI \& KOHAN (1963).

Como o açúcar consumido pela levedura no extrato foi quase total $(99,54 \%)$, o rendimento biologico foi praticamente igual ao rendimento em relação ao substrato: $\eta=18,74 \%$ e. $\eta_{s}=18,66 \%$ (Tabeia 11). Para 1icor $\eta$ foi maior que "s' uma vez que a levedura consumiu somente $55,72 \%$ do açúcar do licor (Tabeila 10 ).

$\mathrm{Na}$ análise do licor após fermentação constatou-se os seguintes teores para os açúcares hidrolisados: melibiose $0,02 \%$, xilose $0,2 \%$, arabinose $0,07 \%$, outros sacarideos 0,02\%, com produção de 0,03\% de xilitol. 
58.

Tabela 10 - Valores de $M_{x f} ; M_{x} ; A_{T} ; A_{c}$ e $A_{c} \%$ de AT no Ensaio I.

\begin{tabular}{|c|c|c|c|c|c|}
\hline \multirow{2}{*}{ REPETI ÇชES } & MASSA DE & CELULA (mg) & AÇÚCAR & $(\mathrm{mg})$ & \multirow{2}{*}{$\begin{array}{c}A \% \\
C^{\% T}\end{array}$} \\
\hline & $M_{x f}$ & $M_{x}$ & $A_{r}$ & $A_{C}$ & \\
\hline \multicolumn{6}{|l|}{ Licor } \\
\hline 1 & 385 & 55 & 791 & 929 & $53,99 \%$ \\
\hline 2 & 391 & 61 & 728 & 992 & $57,67 \%$ \\
\hline 3 & $370^{\circ}$ & 46 & 705 & 955 & $55,51 \%$ \\
\hline$m$ & 384 & 54 & 761 & 959 & $55,72 \%$ \\
\hline \multicolumn{6}{|l|}{ Extrato } \\
\hline 4 & 386 & 56 & 1,6 & 308 & $99,46 \%$ \\
\hline 5 & 387 & 57 & 0,6 & 309 & $99,82 \%$ \\
\hline 6 & 390 & 60 & 2,1 & 307 & $99,32 \%$ \\
\hline$m$ & 388 & 58 & 1,4 & 308 & $99,54 \%$ \\
\hline
\end{tabular}

Tabela 11 - Valores de $R_{x}, n_{s}$, $n, \varepsilon e \varepsilon_{s}$ para o Ensaio I.

\begin{tabular}{llllll}
\hline REPETI C.రES & $R_{x}$ & $n_{s} \%$ & $\eta \%$ & $\varepsilon \%$ & $\varepsilon_{s}$ \\
\hline
\end{tabular}

\section{Licor}

\begin{tabular}{llllll}
1 & 16,70 & 3,20 & 5,93 & 12,49 & 6,74 \\
2 & 18,42 & 3,53 & 6,13 & 12,91 & 7,43 \\
3 & 13,82 & 2,65 & 4,78 & 10,07 & 5,58 \\
\hline$m$ & 16,31 & 3,13 & 5,61 & 11,82 & 6,58 \\
\hline
\end{tabular}

\section{Extrato}

\begin{tabular}{llllll}
4 & 16,85 & 17,95 & 18,05 & 38,08 & 37,79 \\
5 & 17,39 & 18,53 & 18,57 & 39,05 & 39,05 \\
6 & 18,27 & 19,47 & 19,60 & 41,30 & 41,02 \\
\hline$m$ & 17,50 & 18,66 & 18,74 & 39,48 & 39,32 \\
\hline
\end{tabular}


59.

O processo com baixo rendimento, a eficiencia do processo também foi baixa, com $\varepsilon_{s}=6,58 \%$ para 1 icor e $\varepsilon_{s}=39,32 \%$ para extrato. O rendimento e a eficiencia foram baixos o que poderia ser explicado por um consumo de açúcar para a manutenção da células como também pela formação de produtos metabólicos, conforme explicação de SLININGER et alii (1982). A eficiência em relação ao açúcar consumido foi $11,82 \%$ e $39,48 \%$ para 1 icor e extrato respectivamente CTabela 113.

Houve uma porcentagem de crescimento da levedura no licor de $16,31 \%$ e $17,50 \%$ para a levedura crescendo no extrato (Tabela 11). Esperava-se no licor. uma porcentagem de crescimento maior, uma vez que havia maior quantidade de açúcar disponível para a mesma massa de inóculo, açúcar disponf́lel mas não consumido provavelmente por inibição do substrato FANTI \& KOHAN (1963).

o pH medido no final da fermentação, Tabela 12, foi maior que o inicial para licor e para extrato, indicando que houve consumo de ácidos orgánicos durante o crescimento da levedura, fato também observado por HARRIS et alii (1948) e RAMOS (1983) em hidrolisados, diminuindo a acidez acetica no final da fermentação. No pH inicial tanto do extrato como do licor, a levedura cresce satisratoriamente; o aumento de pH torna esse crescimento mais rápido aumentando a utilização de açúcar segundo HAJNY ( 1981 ). 
Tabela $12-p H$ e acidez acética do Ensaio I.

\begin{tabular}{|c|c|c|c|c|}
\hline \multirow{2}{*}{ REPEII ÇひES } & \multicolumn{2}{|c|}{$\mathrm{pH}$} & \multicolumn{2}{|c|}{$\begin{array}{c}\text { ACIDEZ ACETI C.A } \\
(\mathrm{mg} / 100 \mathrm{ml})\end{array}$} \\
\hline & INI CII AL & FINAL & INI C.I AL & FINAL \\
\hline \multicolumn{5}{|l|}{ Licor } \\
\hline $\begin{array}{l}1 \\
2 \\
3\end{array}$ & $\begin{array}{l}5,3 \\
5,3 \\
5,3\end{array}$ & $\begin{array}{l}6,7 \\
6,7 \\
6,7\end{array}$ & $\begin{array}{l}101,40 \\
101,40 \\
101,40\end{array}$ & $\begin{array}{r}8,40 \\
8,40 \\
14,40\end{array}$ \\
\hline \multicolumn{5}{|l|}{ Extrato } \\
\hline $\begin{array}{l}4 \\
5 \\
6\end{array}$ & $\begin{array}{l}4,1 \\
4,1 \\
4,1\end{array}$ & $\begin{array}{l}5,3 \\
5,6 \\
5,5\end{array}$ & $\begin{array}{l}42,60 \\
42,60 \\
42,60\end{array}$ & $\begin{array}{l}21,60 \\
12,00 \\
18,00\end{array}$ \\
\hline
\end{tabular}

\subsubsection{Ensaios II, III, IV e $Y($ com aeraçá)}

As condiçōes experimentais dos ensaios II a $V$, apenas com aeração, "estão demonstradas na Tabeja 13.

Tabela 13 - Condiçoes experimentais dos Ensaios II, III, IV e. V (com aeração).

\begin{tabular}{lcccc}
\hline VARI AVEIS & II & III & IV & $V$ \\
\cline { 2 - 5 } & 68 & 60,8 & 69,2 & 65,97 \\
$U_{x}(\%)$ & 320 & 392 & 308 & 340 \\
$M_{x 0}(\mathrm{mg} / 100 \mathrm{ml})$ & 100 & 100 & 100 & 100 \\
$V(\mathrm{ml})$ & 310 & 310 & 310 & 310 \\
$A_{1}(\mathrm{mg} / 100 \mathrm{ml})$ & 1720 & 1720 & 1720 & 1720 \\
AT $_{z}(\mathrm{mg} / 100 \mathrm{ml})$ & & & & \\
\hline
\end{tabular}


61.

Nos ensaios II, III, IV e V com o extrato de bagaço, houve um consumo médio de açúcar com relaçắo ao açúcar total varíando de 95,49 a $99,90 \%$ e para o licor de 52,08 a $66,34 \%$ (Tabela 14 ).

o rendimento médio em relação ao açúcar total no extrato em cellulas de leveduras $\left(n_{s}\right)$ variou de 10,53 a $22,95 \%$ e o rendimento médio em relação ao açúcar consumido para extrato (n) variou de 10,60 a $24,04 \%$ (Tabela 15) com desempenho alternativo entre os ensaios para as mesmas condiçōes. Relacionando o rendimento biológico (n) com o rendimento tesrico de HARRISON, 1971: 47,5g de levedurapioOg de glucose, obtem-se eficiencias de processos biológicos (e) variando de 22,32 a $50,58 \%$. Esses resultados levam a concluir que possivelmente outros produtos foram formados, como etanol, não detectado para extrato, nos Ensaios II, III e $V$, mas provavelmente produzido pela levedura. Procurou-se no Ensaio IV, com aeração, através de análises a intervalos de 4 horas, verificar o teor em álcool formado durante a fermentação. Os resultados se encontram na Tabela 16. A quantidade de alcool detectada na primeira amostragem foi decrescendo até não dar mais álcool na terceira amostragem, - que evidencia um consumo de álcool pela levedura e se permite supor que nos ensaios anteriores onde não se detectou álcool no final da fermentaça, ele possa ter-se formado. 
62.

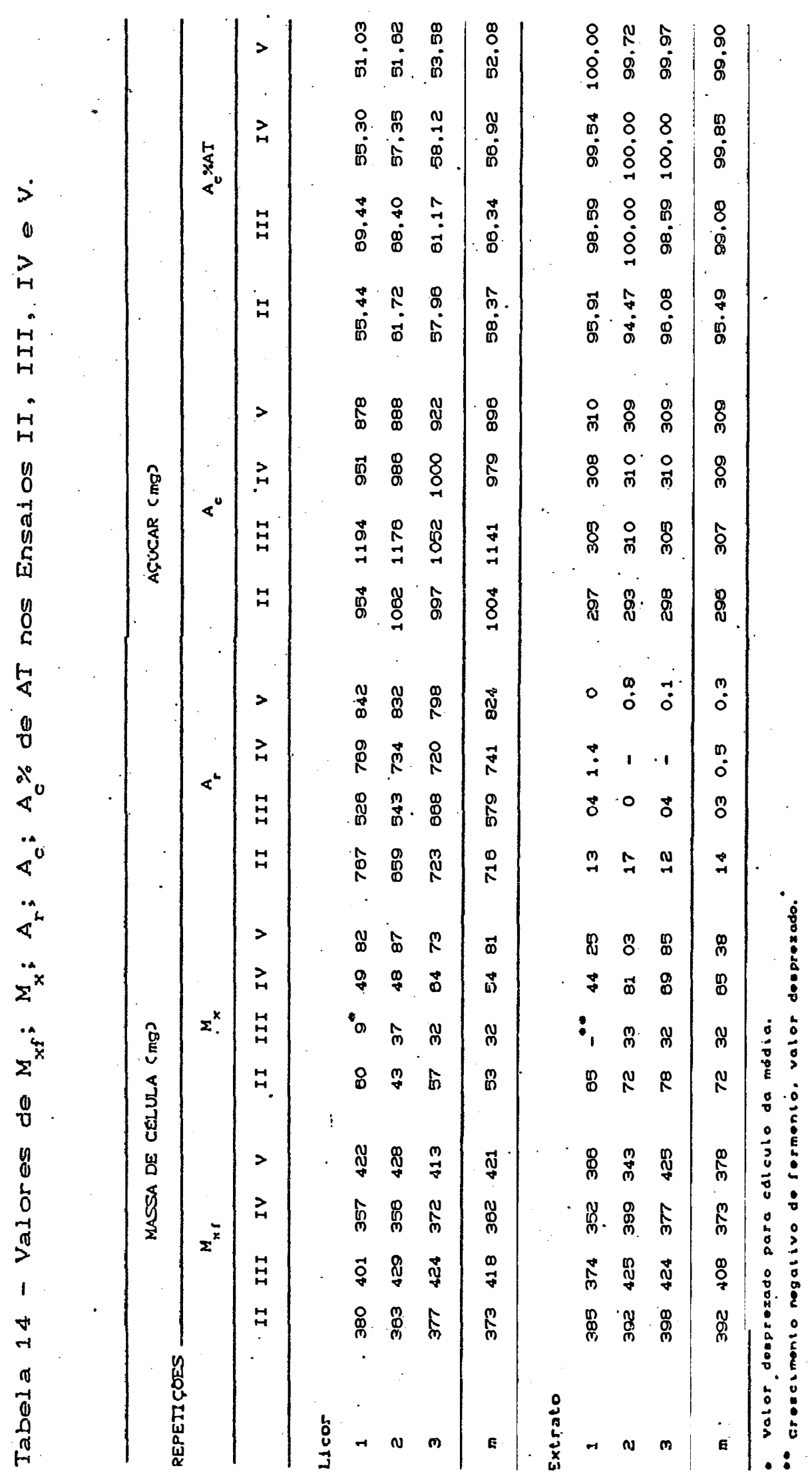




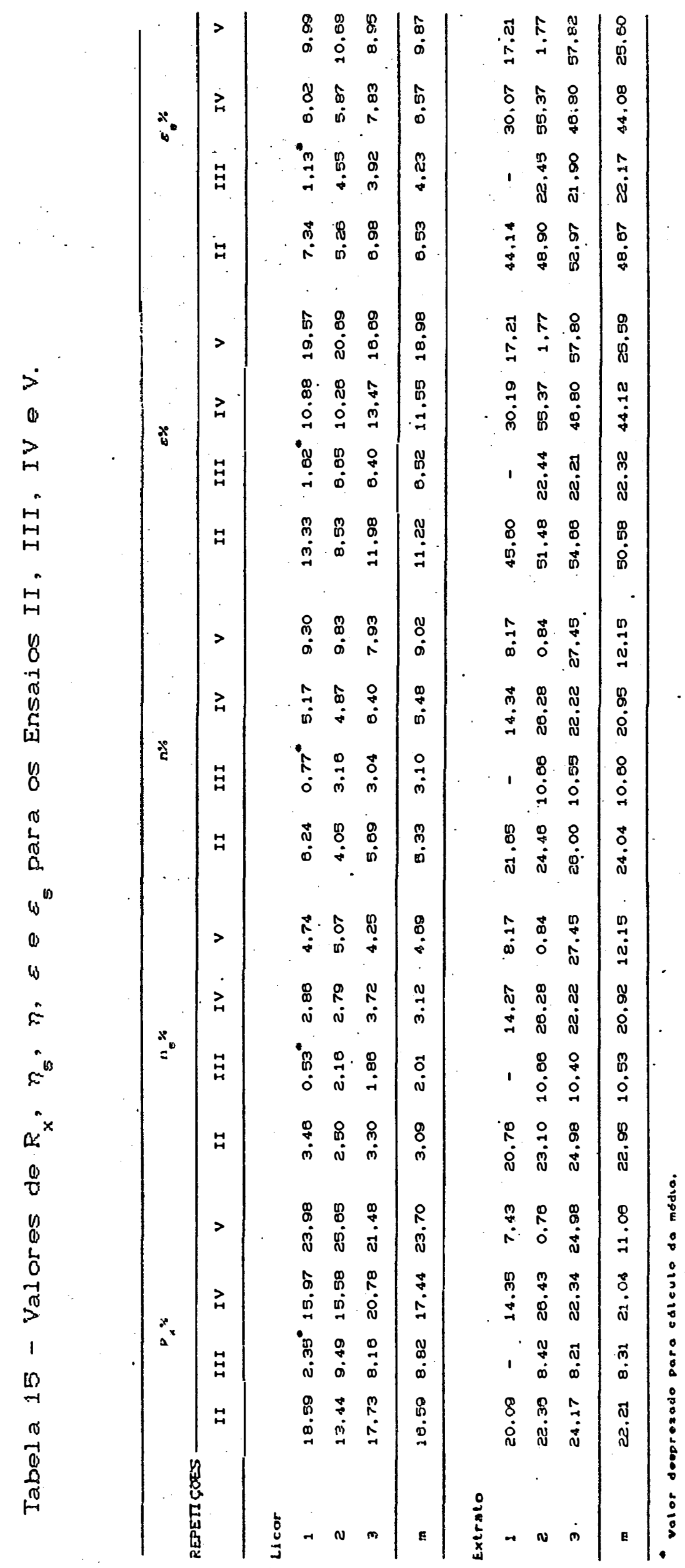

63. 
64.

Tabela 16 - Dosagens de Etanol no Ensaio IV (ml/100ml).

\begin{tabular}{lcccc}
\hline & \multicolumn{5}{c}{$\%$ ETANOL EM VOLUME } \\
\cline { 2 - 5 } REPETI ÇZES & APÓS 4h & APÓS 8h & APÓS 16h & FINAL \\
\hline Licor & & & & \\
1 & 0,03 & 0,01 & 0,00 & 0,00 \\
2 & 0,09 & 0,02 & 0,01 & 0,00 \\
3 & 0,03 & 0,02 & 0,00 & 0,01 \\
\hline$m$ & 0,05 & 0,02 & 0,00 & 0,00 \\
\hline Extrato & & & 0,00 & 0,00 \\
4 & 0,05 & 0,03 & 0,01 & 0,01 \\
5 & 0,02 & 0,01 & 0,00 & 0,01 \\
\hline 6 & 0,02 & 0,03 & 0,00 & 0,00 \\
\hline$m$ & 0,03 & 0,02 & & \\
\hline
\end{tabular}

Parece que pouco açúcar no extrato mais o alcool que poderia ter-se formado foram suficientes apenas para manutençăo e pequeno crescimento celular nos ensaios no periodo de 24 horas.

Como o teor de furfural no licor era baixo, $36 \mathrm{ppm}$ e provavelmente sem causar problemas, foi testado o aumento de inóculo de 1 para $2 \%$ de fermento em relaçáo ao substrato, porque um volume maior de inoculo, segundo LEONARD \& HAJNY (1945) pode ser usado para vencer um possi-.. vel potencial de oxido reduçăo desfavorável. O rendimento permaneceu baixo. Para. PETERSON et ali i (1945), um inoculo de $4 \mathrm{~g}$ de matéria seca por $1 \mathrm{itro}(0,4 \mathrm{~g}$ por $100 \mathrm{ml})$ é considerado um inoculo "pesado", com periodo de fermentaçăo mals curto, principalmente à temperatura de $34-35^{\circ} \mathrm{C}$, a qual 
65.

favorece a produção de álcool. Nos ensaios deste trabalho o inóculo a $1 \%$ de fermento prensado, aproximadamente $0,3 \mathrm{~g}$ matéria seca por $100 \mathrm{ml}$ de substrato já representava uma concentração elevada de célul as de levedura.

As eficiéncias do Ensaio $V$ foram para licor: 9,87 em relação ao açúcar total do substrato e $18,98 \%$ em rel ação ao açúcar consumido e para extrato, $25,60 \%$ e $25,59 \%$, respectivamente (Tabela 15). Estes resultados de maneira geral, são maiores do que os demais para o licor e menores do que os do extrato.

A razão de crescimento celular no Ensaio $V$ foi $23,70 \%$ para levedura crescendo no licor e $11,06 \%$ para a levedura crescendo no extrato (Tabela 15), com comportamento semelhante do demonstrado para as eficiencias.

Comparando o rendimento em célula de levedura em relação ao açúcar total (ns) para licor, que variou de 2,01 a 4,69\% com o rendimento em relação ao açúcar total para extrato $\left(\eta_{s}\right)$ de 10,53 a $22,95 \%$ (Tabela 15$)$, o rendimento no licor $\left(\eta_{s}\right)$ foi sempre significativamente menor que o rendimento no extrato $\left(\eta_{s}\right)$.

Esta observação refiorça a hipótese de que uma mistura de hexoses e pentoses por si só é um fator inibitório de fermentação (FANTI \& KOHAN, 1983) e que outros inibidores de fermentação podem ser encontrados nos hidrolisados lignocel ulósicos provenientes da hemicelulose, da lignina e extrativos da matéria-prima, apontados por TRAN \& CHAMEERS (1986), cujos compostos não foram ainda estudados. 
66.

Os bai xos valores encontrados para o rendimento devem estar associados a possível formação de etanol e de outros componentes como xilitol e arabitol.

Relacionando o rendimento em células de levedura em relação ao açúcar consumido do licor (n) com o rendimento em relação ao açúcar conșumido do extrato, o rendimento (n) do licor. $(3,10$ a $8,02 \%$ foi da ordem, de três a quatro vezes menor que o rendimento (n) no extrato $(10,60$ a 24,04), o que se verificou tambem no Ensaio I (Tabela 11 ). Isto demonsta que, provavelmente outros produtos foram formados como etanol, xilitol ou arabitol ou que D-xilose, principal componente da pré-hidrólise, não foi usada para crescimento da levedura como observou HSIAO et ali i (1982).

As eficiências do processo em relação ao açúcar total do substrato (e ${ }_{s}$ variaram de 4,23 a $6,53 \%$ para licor e de 22,17 a $48,67 \%$ para extrato. As eficiéncias do processo em relação ao açúcar consumido foram de 6,52 a $18,98 \%$ para 1 icor e de 22,32 a 50,58\% para extrato CTabela 15), demostrando as dificuldades encontradas pela levedura em meios com diferentes fatores de inibição.

A razão de crescimento celular foi de 8,82 a $23,70 \%$ para a levedura crestendo no 1 icor e de 8,31 a 22,21\% para a levedura crescendo no extrato (Tabela 15 ).

o pH final dos ensaios oscilou de 6,62 a 8,30 para licor e de 4,62 a 6,48 para extrato, pH final de fermentação acima do $\mathrm{pH}$ inicial para cada substrato, Tabela 17 , com consumo de ácidos orgânicos segundo HARRIS ot alii (1948), da mesma maneira que ocorreu no Ensaio I. 
67.

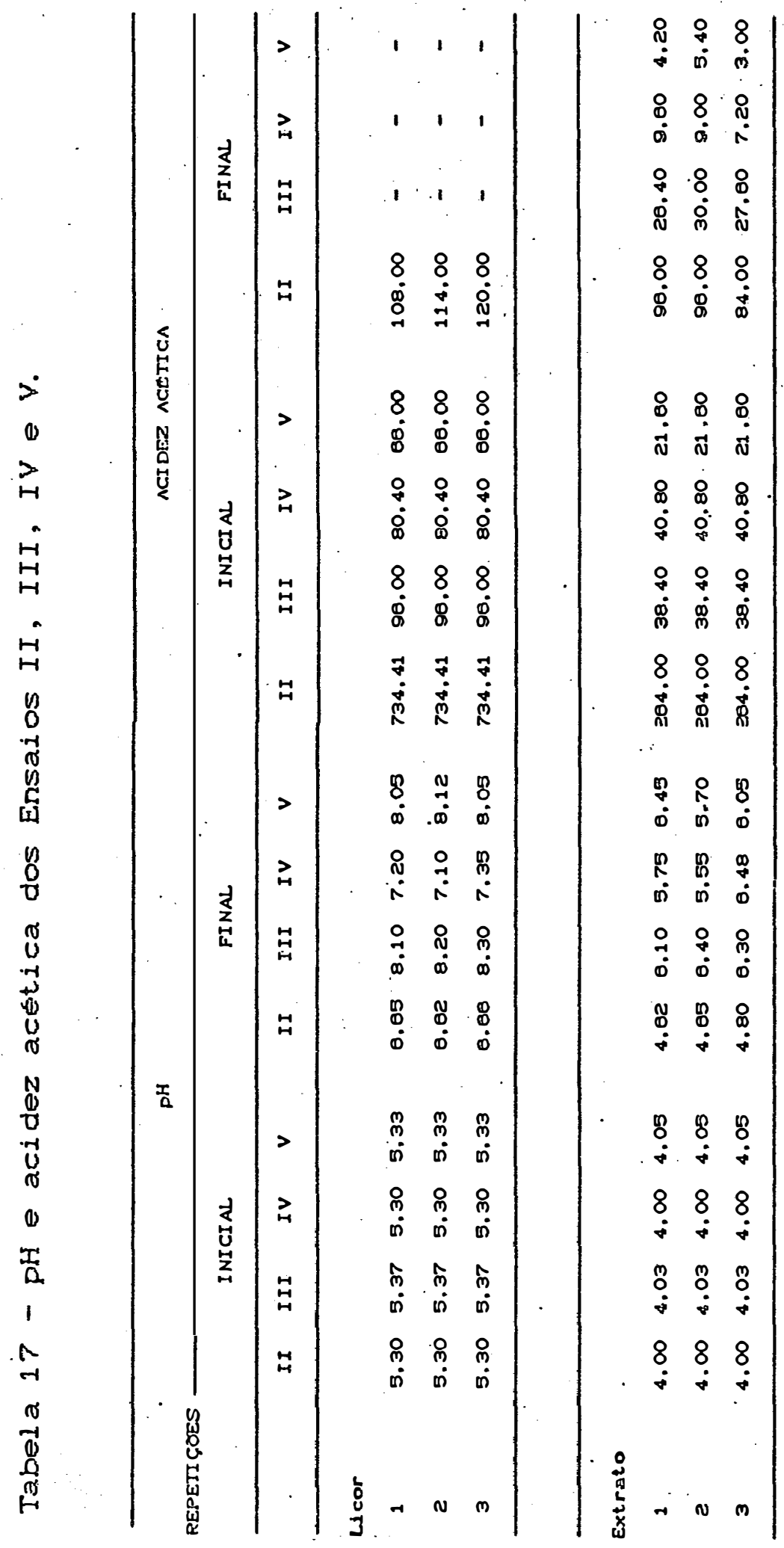


68.

\subsubsection{Ensaios VI, VII, VIII e IX Ccom aeraçăo e suplementaçăo de sais?.}

As condiçơes experimentais dos Ensaios de VI a IX, são apresentadas na Tabela 18.

Tabela 18 - Condiçóes experimentais dos Ensaios VI, VII, VIII e IX (com aeração e suplementação de sais).

\begin{tabular}{lcccc}
\hline & \multicolumn{4}{c}{ ENSAIOS } \\
\cline { 2 - 5 } VARI ÁVEIS & VI & VII & VIII & IX \\
\hline$U_{x}(\%)$ & 68,1 & 69,6 & 69,1 & 68,1 \\
$M_{x 0}(\mathrm{mg} / 100 \mathrm{ml})$ & 319 & 304 & 309 & 319 \\
$V(\mathrm{ml})$ & 100 & 100 & 100 & 100 \\
$\mathrm{AT}_{1}(\mathrm{mg} / 100 \mathrm{ml})$ & 310 & 310 & 310 & 310 \\
$\mathrm{AT}_{2}(\mathrm{mg} / 100 \mathrm{ml})$ & 1720 & 1720 & 1720 & 1720 \\
\hline
\end{tabular}

Nos ensaios VI,. VII, VIII e IX foram feitas suplementaçőes de sais dos substratos com nitrogênio, fósforo e potássio. Houve uma reação significatica para licor alcançado rendimento em leveduras variando de 5,51 a $20,99 \%$ em relação ao açúcar total do substrato e de 8,49 a 27,72\% em relação ao açúcar consumido (Tabela 19), valores estes bem maiores do que os obtidos para os Ensaios $I$ a $V$, nos quais não foi feita a suplementação. 
69.

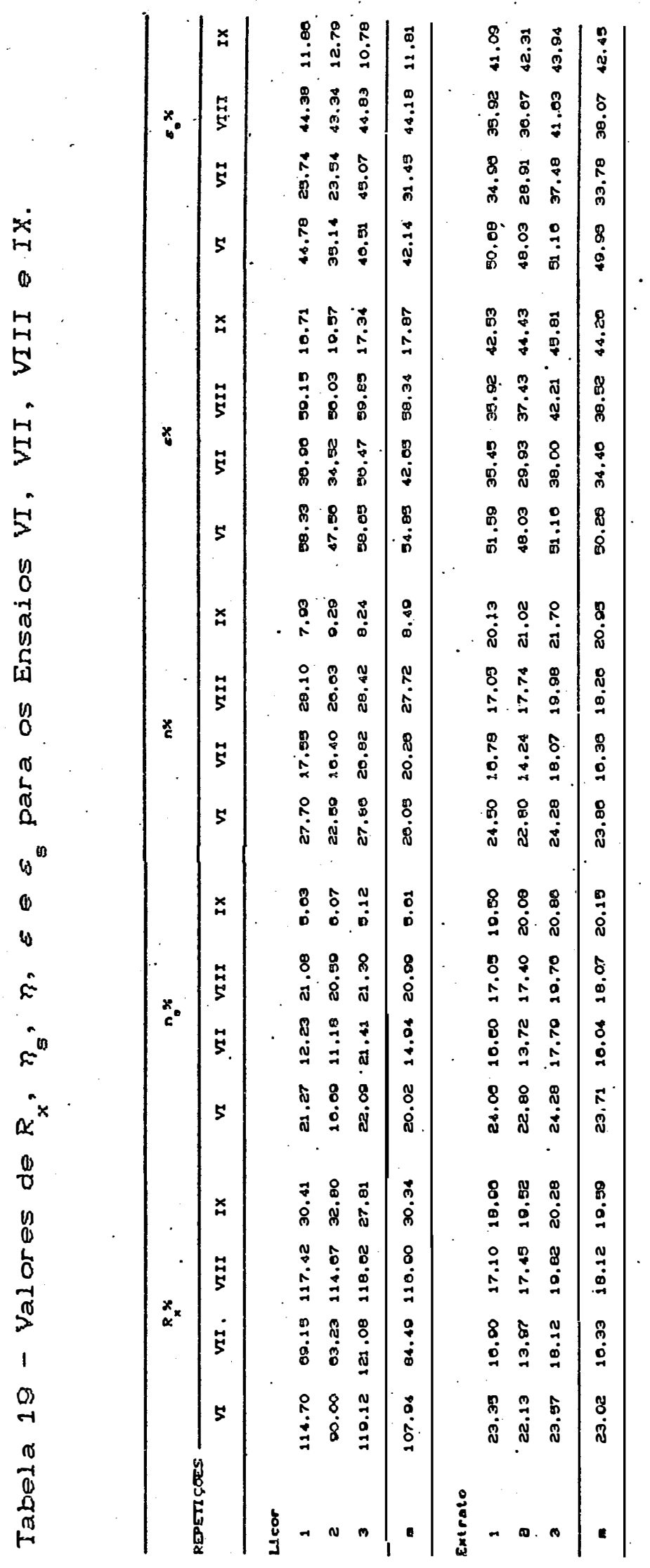


70.

A porcentagem de açúcar consumido no licor pelas células de levedura foi de 66,18 a 76,65\% (Tabela 20 , - que indicaria o consumo total ou quase total dos açúcares do licor, segundo HARRIS et aiii (1948), que encontrou uma porcentagem de $25 \%$ de substâncias redutoras não açúcares após o término da fermentação em hidrolisado quando $75 \%$ de açúcar haviam sido consumidos. Este consumo também foi maior do que o verificado para os ensaios sem suplementação.

Nos ensaios VI e VIII verificou-se que o rendimento encontrado em células secas de levedura no licor, em relação ao açúcar' total (Tabela 19), está próximo ao observado por JOHNSON \& HARRIS (1948) para Saccharomyces cerevisiae na primeira transferencia, de uma série de transferencias da levedura em hidrolisado com aproximadamente .5\% AT. Mas, deve-se salientar que nos ensaios VII e IX este rendimento esteve inuito aquém daqueles observados pelos mesmos autores (Tabela 3).

As eficiéncias foram de 11,81 a $44,18 \%$ em relação ao açúcar total do licor e de 17,87 a $58,34 \%$ em relação ao açúcar consumido (Tabela 19), também denotando eficiencias maiores do que os ensaios não suplementados (Tabelas 11 e 15). Com pH final de fermentação ao redor de 7,50 , com consumo de ácidos orgánicos pelas células de levedura (Tabela êl), observa-se o mesmo comportamento do que para os demais ensaios. (HARRIS ei ai $i$, 1948 ).

A razão de crescimento celular variou de 30,34 a $116,90 \%$ (Tabela 19), significativamente maior do que a dos ensaios não suplementados (Tabel as 11 e 15 ). 
71.

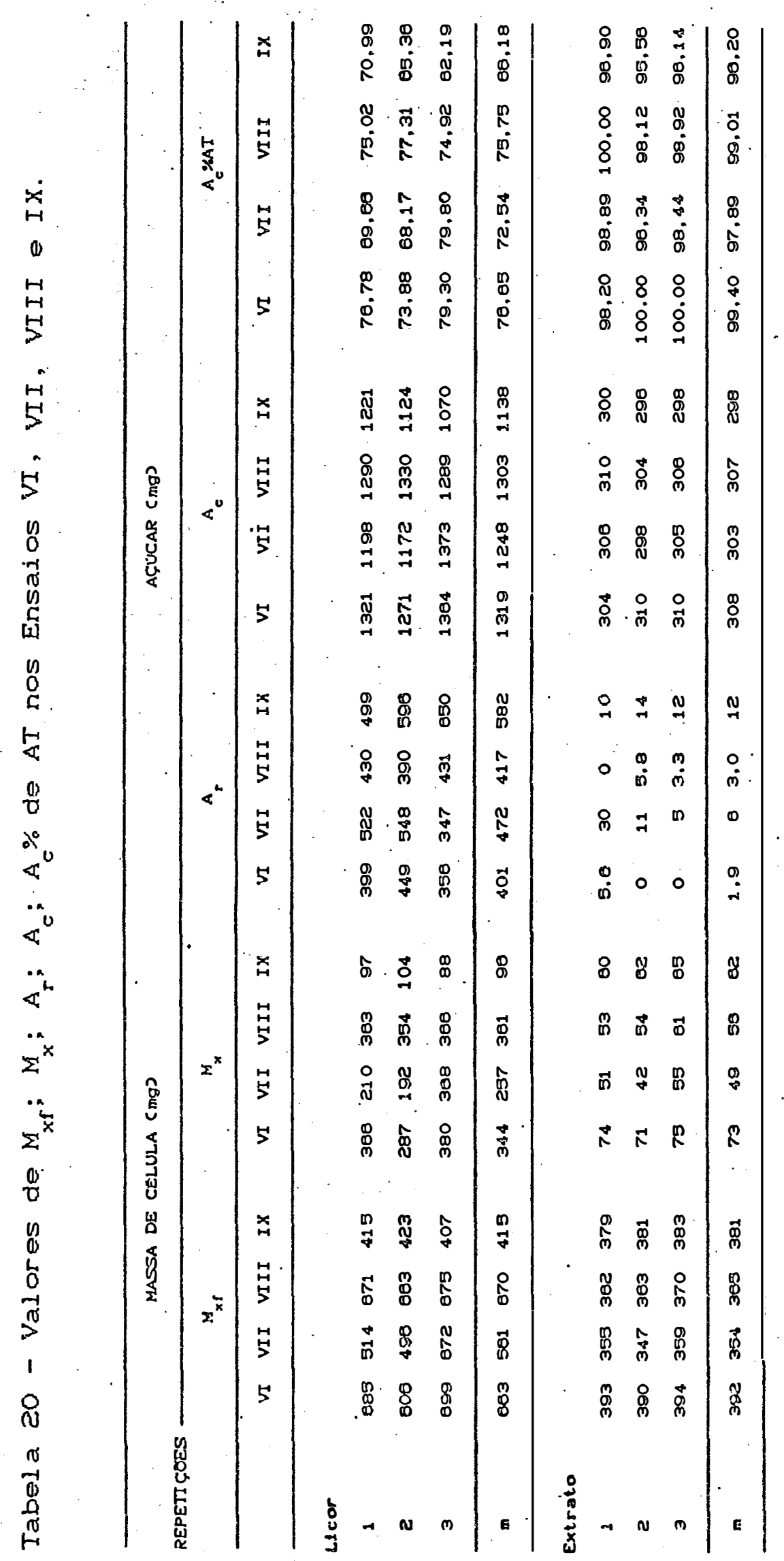


Para extrato encontrou-se nos Ensaios VI a IX, rendimento em células secas de levedura em relação ao açúcar total do extrato variando de 16,04 a $23,71 \%$ e de 16,36 a $23,86 \%$ em rel ação ao açúcar consumido, Tabela 19 . Os rendimentos para extrato nos ensaios VI a IX, foram de maneira geral pouco superiores aos encontrados para extrato nos ensaios II a $V$, com aeração e sem suplementação de sais (Tabela 15). Isso se deve, talvez, ao fato de que as quantidades de nutrientes existentes nos substratos já se encontravam ao nivel das necessidades da levedura.

As eficiencias para extrato nos Ensaios VI a IX foram: eficiência em relação ao açúcar total do substrato variando de 33,78 a $49,96 \%$ e eficiéncia em relação ao açúcar consumido de 34,46 a 50,26\%, (Tabela 19 , com 96,20 a 99,40\% de açúcar consumido. do total do açúcar do extrato, Tabela 20. A razão de crescimento celular encontrada nos Ensaios VI a IX para a levedura crescendo no extrato teve uma variação de 16,33 a 23,02\% (Tabela 19), da mesma ordem dos ensaios não suplementados.

Os baixos rendimentos e eficiencias encontraods em todos os ensaios para levedura crescendo no extrato, talvez sejam explicados pelo baixo teor de açúcar total, igual a 0,31\%, utilizado não só para crescimento mas também manutenção das células num período de 24 horas, em fermentação em batelada, sem alimentação de substrato.

o pH final de fermentação no extrato variou de 7,0 a 8,5 (Tabela 21), indicando consumo de ácidos orgânicos 
73.

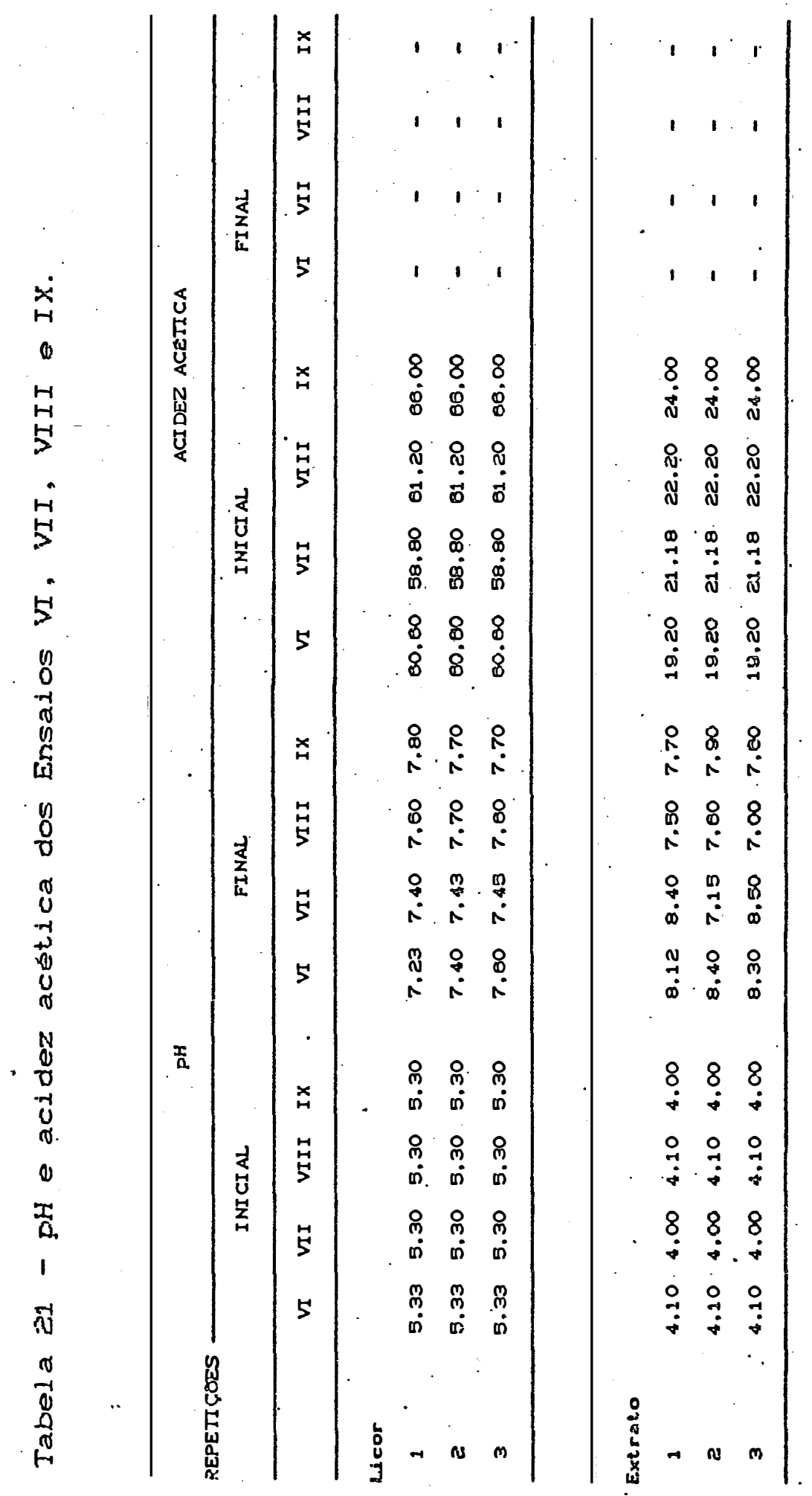


pela levedura, conforme HARRIS et alii (1948), considerando o que ocorreu também nos demais ensaios (Tabelas 12 e 17 ).

Os rendimentos em células secas de levedura em relação ao açúcar total foram reunidos na Tabela 22 , a qual dá uma visualização das modificaçôs realizadas nos Ensaios com a finalidade de melhorar a fermentaçăo e os resultados alcançados nessas fermentações.

Tabela 22 - Rendimento em massa seca de cellulas de levedura em relação ao açúcar total do extrato do digestor e do licor (\%). CMédia de 3 repetiç̧es para $\eta_{s}{ }^{3}$

\begin{tabular}{|c|c|c|c|c|c|c|c|c|}
\hline & * & 苏为 & 米米 & *** & ***** & **** & 米称消 & 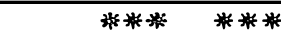 \\
\hline ENSAIOS & $\mathbf{I}$ & II & III & I V & $\mathbf{v}$ & VI & $V I I$ & VIII \\
\hline
\end{tabular}

SUBSTRATOS

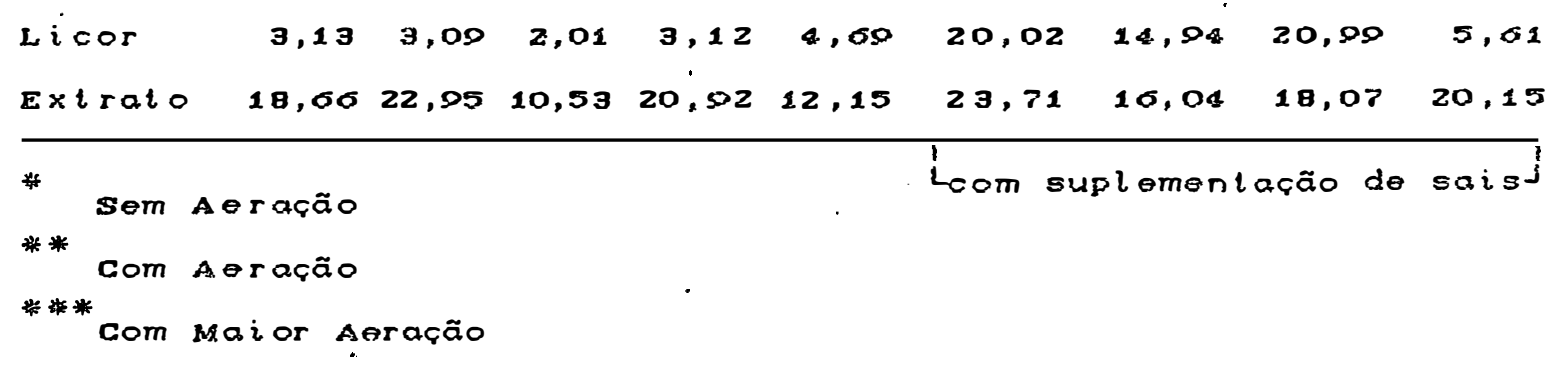

Esses rendimentos foram calculados sobre o açúcar total das soluçðes 1 icor e extrato. Transformando o açúcar total do licor e o açúcar total do extrato de bagaço em açúcar total porcento bagaço, foram obtidos açúcar tolal do licor igual a 7,79\% bagaço e açúcar total do extrato igual a 3,26\% bagaço (Tabela 6). Fazendo a conversão dos rendimentos em células secas de levedura em relação ao subs- 
75.

trato para quilograma de levedura por $100 \mathrm{~kg}$ de bagaço, os resultados para $\eta_{s}$ passaram a ser os da Tabela 23 onde se observa que nos Ensaios VI, VII e VIII, com suplementação de nutrientes, o licor apresentou um maior rendimento em levedura por $100 \mathrm{~kg}$ de bagaço processado comparado com o extrato.

Tabela 23 - Rendimentos médios em leveduras em relação aos açúcares totais do licor e extrato em $\mathrm{kg}$ por 100 kg bagaço.

\begin{tabular}{llllllllll}
\hline ENSAIOS & I & II & III & IV & $V$ & $V I$ & $V I I$ & VIII & IX \\
\hline SUESTRATOS & & & & & & & & & \\
Licot & 0,24 & 0,24 & 0,10 & 0,24 & 0,37 & 1,56 & 1,17 & 1,64 & 0,44 \\
Exitato & 0,61 & 0,75 & 0,34 & 0,68 & 0,30 & 0,77 & 0,52 & 0,50 & 0,60 \\
\hline
\end{tabular}


76.

\section{CONCLUSÕES}

1. Com a pré-hidrólise do bagaço houve desdobramento de hemicelulose em melibiose, glucose, xilose e arabinose, aumentando o teor de açúcares no licor.

2. Foi obtido crescimento de saccharomyces cerevisiaé no pré-hidrolisado de bagaço de cana-de-açúcar com maior produção de massa seca de cellulas quando o licor foi suplementado com nitrogênio e potássio.

3. Constatou-se que houve consumo de xilose pela levedura com produção de xilitol.

4. Nas concentraçßos utilizadas de açúcar total no licor - extrato de bagaço a produção de leveduras por quilograma de bagaço foi maior no licor que no extrato.

5. Existem substancias inibidoras desconhecidas que prejudicaram o crescimento da levedura no licor de bagaso de cana-de-açúcar. 
6. Não compensa a produção de leveduras a partir de licor de bagaço obtido por autoclavagem nas condiçð̋es estudadas. 
78.

\section{REFERENCI AS BIBLIDGRAFICAS}

AMORIM, H.V.; ZAGOO, E. A.; OLIVEIRA, A.J. Análises para o cọtrole da fermentaçáo alcoólica e aparel hos de destilação. Piracicaba, ESALQ, 1979. $50 \mathrm{p}$.

BANERJEE, N.; BHATNAGAR, R. ; VISWANATHAN, L. Inhibition of glycolysis by furfural in Saccharomyces cerevisiae. Applied Picrobiology and Biotechnology, Berlim, 11: 226-8, 1981 .

BERTO, D. A. Levedura seca de destilaria de álcool de cana-de-açúcar (Saccharomyces spp) na alimentação de leitões em recria. Piracicaba, 1985.133 p. CMestrado Escola Superior de Agricultura "Luiz de Queiroz"

BORZANI, W. \& AQUARONE, E. Effect of arabinose on gl ucose fermentation by Saccharomyces cerevisiae. Applied Microbiology, Baltimore, 6(4): 225-8, Jul. 1958.

BUENO NETTO, c. L. Influência da concentração inicial de células e do tempo de enchimento da dorna do processo desciontínuo alimentado de fermentação alcoólica de mosto de melaço de cana-de-açúcar. Sao Paulo, 1982. 147 p. (Mestrado Escola Politécnica/USP).

CAMPOS NETO, O.; GONÇALVES, H. C. ; ZEZZA NETO, L. Utilizacão do bagaço de cana hidrolisado e levedura seca c Saccharomyces cerevisiae), residuo da produçäo de álcool na ali.. mentação de cabra leiteira. In: REUNI TO ANUAL DA SOCIEDA- 
79.

DE BRASI LEIRA DE ZOOTECNIA, 24., Brasilia, 1987. Anais. Brasilia, S.B.Z., 1987 . P. 123.

CIRILLO, V.R. Relationship between sugar structure and competition for the sugar transport system in baker's yeast. Journal of Bacteriology, Baltimore, 95(2): 603-11, Feb. 1968.

COOPERATIVA DOS PRODUTORES DE C.ANA, AÇÚCAR E ÁLCOOL DO ESTADO DE SÃO PAULO LTDA. Controle qui mico da fabricaçáo do açúcar. Piracicaba, 1978. $127 \mathrm{p}$.

D'ARCE, R.D. \& MACHADO, P.F. Residuos agroindustriais da cana-de açúcar na alimentação de ruminantes. In: D'ARGE, R.B., BOIN, C.; MATTOS, W.R.S. Utilização de resíduos agroindustriais na alimentação de ruminantes. Piracicaba, FEALQ, 1985. p. 1-17.

DELGADO, J.U.; AGUILERA, R.C., GARCiA, A.G. Produtos dé 1 a hidrólisis de los derivados de la caña de azúcar. In: INSTI TUTO CUBANO DE INVESTIGAGIONES DE LOS DERIVADOS DE LA CAAAA DE AZÚGAR. La indústria de los derivados de la caña de azúcar. La Habana, Ed. Cientifico - Técnica, 1986. Cap. 9, $251-76$.

DE MARTIN, V.F. Efeito da remoção de células sobre o rendimento da fermentação alcólica por leveduras. Piracicaba, 1987. 188 p. CMestrado - Escola Superior de Agricultura "Luiz de Queiroz" $(U S P)$.

DESMONTS, R. Tecnologia da produção dos fermentos secos de destilaria. Boletim Informativo da A.P.M., Piracicaba, 8(2): 1-11, jun., $1966 a$.

DESMONTS, R. Importancia do fermento seco na luta cta subnutrição protéica e a carência vitaminica B. Boletim 
80.

Informativo da A.P.M., Piracicaba, 8(4): 5-14, dez., $1966 b$.

DULANEY, E.L.; STAPLEY, E. O.; SIMPF, K. Studies on érgosterol production by yeasts. Applied Microbriology, Baltimore, 2(6): 371-9, Nov., 1954.

DU TOIT, P.J.; OLIVIER, S.P.; VAN BILJON, P.L. Sugar cane bagasses as a possible source of fermentable carbohydra-tes. I. Characterization of bagasse with regard to monosaccharide, hemicellulose, and amino acid composition. Biotechnology and Bioengineering, New York, 26: $1071-8$, 1984.

FANTI, O.D. \& KOHAN, T. Fermentation y desarrollo de levaduras en hidrolizados de materiales celulosicos. Revista de Investigaciones Agricolas, Buenos Aires, 17(3): 273-87, 1963.

FAZANO, A.R.T. Digestibilidade e valor biológico da proteina da levedura seca (Saccharomyces spp) e do farelo de soja para coelhos. Piracicaba, 1986. 64 p. CMestrado - Escola Superior de Agriculturà "Luiz de Queiroz" $/$ USP).

FIALHO, E. T. ; GOMES, P. C. ; ALBINO, L.F.T. ; COSTA, V. Determi nação de valores de composição química e de digestibilidade de alguns ingredientes nacionais para suinos. Revista da Sociedade Brasileira de Zootecnia, Viçosa, $12(2): 337-56,1983$.

FLANNERY, R.J. Nonagricultural sources of food. Food Technology. Champain, 29(8): 64-6, Aug. 1975.

FREY, C. N. History and development of the modern yeast industry. Industrial and Engineering Chemistry, Washington, $22(11): 1154-62,1930$. 
81.

GLORIA, N.A. \& SANTA ANA, A.G. Métodos de análises de residuos de usinas de açúcar e destilarias. Revista de Agricultura, Piracicaba, 1(1/2): 37-8, out., 1975.

GOMORI, G. A modification of the colorimetric phosphorus determination for use with the photoeletric colorimeter. Journal of Laboratory and Clinical Medicine, St. Louis, $27: 955-60,1942$.

GONG, C. ; CHEN, L. ; FLICKINGER, M. C. ; CHIANG, L. ; TSAO, G. T. Production of ethanol from D-xylose by using D-xylose isomerase and yeasts. Applied Environmental Microbriology, Washington, 41(2): 430-6, Feb. 1981.

GONG, C. ; C.LAYPOOL, T. A. ; MCC.RACKEN, L. D. ; MAUN, C. M. ; UENG, P.P. ; TSAO, G.T. Conversion of pentoses by yeasts. Biotechnology and Bioengineering, New York, 25(1): 85-102, Jan. , 1983.

GUSAROVA, L. A. Effect of furfural on the biosynthesis of protein and nucleic acids by yeast, condida tropicalis. Prikl. Biokhim. Mikrobiol. 6(5): 509-15, 1970. Apud Chemical Abstracts, Easton, 74(3): 211, ref. $11869,1971$. (Resumo).

HAJNY, G.L. Biological utilization of wood for production of chemicals and roodsturfs, Madison, USDA. Forest Product,s Lab., 1981 . (For, Serv. Res. Pap. FPL, 3853.

HARRIS, E.E.; SAEMAN, J.F.; MARQUARDT, R.R. ; HANNAN, M. L. ; ROGERS, S.C. Fodder yeast from wood hydrolysates and still residues. Industrial and Engineering Chemistry, Washington, 40(7): 1220-3, Jul., 1948.

HARRISON, J.S. Yeast production. Progress in Industrial Microbiology, New York, 10: 129-77, 1971. 
82.

HORII, J. \& STUPIELLO, J.P. Determinaçăo de álcool; teor alcólico da vinhaça. Piracicaba, ESALQ, Departamento de Tecnologia Rural, 1970. 3 p. (Mi meografado).

HSI AO, H.I.; CHI ANG, L. C. ; UENG, P.P. ; TSAO, G.T. Sequential-utilization of mixed monosacharides by yeasts. Applied and Environmental Microbiology, Washington, 43: 840-5, Apr. 1982.

HSU, W. Protein from sugar on Taiwan. Sugar y Azúcar, New York, 56(7): 33-6, 1961.

INSTITUTO CUBANO DE INVESTIGACIONES DE LOS DERIVADOS DE LA CAAAA DE AZÚC.AR. Bagaço. In: La Indústria de los Derivados de la Caña de Azucar. La Habana, Ed. Científico-Técnica, 1986 . cap. 4, p. $111-30$.

JEFFRIES, TH. W. Utilization of xylose by bacteria, yeast and fungi. Advances in Biochemical Engineering Bi otechnology, New York, 27: 1-32, 1983.

JOHNSON, M.C. \& HARRIS, E.E, Acclimatization of various yeasts to wood sugar. Journal of the American Chemical Society, Easton, 70(9): 2961-3, Sept., 1948.

JOSLYN, M. A. Alcoholometry. In: ___, ed. Methods in food analysis. 2 ed. . New York, Academic Press, 1970 . cap. 15, p. $447-74$.

KATAGIRI, $H$. The influence of the fatty acids and their salts on alcoholic fermentation by living yeast. Part $I$. Acetic and formic acids and their sodium, potassium and ammonium salts. Biochemical Journal, Cambridge, 20(2): $427-36,1926$. 
83.

KILBERG, R. The microbe as a source of rood. Annual Review of Microbiology, California, 26: 427-66, 1972.

KLING, S.H.; BARBOSA, M.F.S: ; OLIVEIRA, W. Aproveitament:o. integral doś resíduos 1 ignocelulósicos em particular do bagaço de cana-de-açúcar. In: SEMANA DA FERMENTAÇ.̃̃O ALCOOLICA, 4, Piracicaba, 1985. Anais. Piracicaba, ESALQ/ STAB, 1985 . p. 62-70.

KLING;, S.H.; CARVALHO NETO, C. ; FERRARA, M.A; TORRES, J.C.R. ; MAGALHÃES, D.B. ; RYU, D. D.Y. Enhancement of enzymatic hydrolysis of sugar cane bagasse by steam explosion pretreatment. Biotechnology and Bioengineering, New York, $29(8): 1035-9,1987$.

KRONKA, R.N.; C.URTARELLY, S. M.; KRONKA, S. de N.; ALCADEPANI, D. ; RAMOS, I. A. Uso da levedura seca CSaccharomyces cerevisiael de destilaria de álcool de cana-de-açúcar e fare10 de arroz na alimentaçăo de suinos (experimento 2). In: REUNI TO ANUAL DA SOCIEDADE BRASILEIRA DE ZOOTECNIA, 24., Brasilia, 1987. Anais, Brasilia, S. B.Z., 1987. p. 001.

LACORTE, M.C.; BURGI, R.; LACORTE, A.J.F. Bagaço de cana hidrolisado já utilizado em larga esçala em confinamento. STAB; Açúcar e Álcool e Subprodutos, Piracicaba, 5(2): 43-52, nov. /dez., 1986.

LEONARD, R. H. \& HAJNY, G.L. Fermentation of wood sugars to ethyl alcohol. Industrial and Engineering Chemistry, Washington, 37(4): 390-5, Apr. 1945.

LIMA, G.J.M.M. de. Uso de levedura seca (Saccharomyces cerevisiael de destilaria de álcool de cana-de-açúcar na alimentação de matrizes suinas em gestação e lactaçăo. Piracicaba, 1983. 139 p. CMestrado - Escola Superior de Agricultura "Luiz de Queiroz" $/$ USP). 
84.

LIMA, O.G. Desenvolvimento da indúst.ria da levedura alimentar a contribuiçăo brasileira. Brasil Açúcareiro, Rio de Janeiro, 67(3): 24-45, mar. 1966.

MACHADO, P.F. Valor nutritivo da levedura, residuo da produção do álcool para vacas em lactação. Piracicaba, 1983. 110 p. CDoutorado - Faculdade de Ciéncias Farmacêuticas $/$ USPJ.

MACHADO, P.F.; D'ARCE, R. D. ; MATTOS. W.R. S. Valor nutritivo da levedura seca (Saccharomyces Sp.) para ruminantes. I. Consumo digestibilidade, produção e composição do leite. In: REUNÃO ANUAL DA SOCIEDADE BRASILEIRA DE ZOOTECNIA, 20., Pelotas, 1983. Anais, Pelotas, S.B. Z., 1983. p. 81.

MATTOS, W.R.S.; D'ARCE, R. D. ; MACHADO, P.F.; MARCOS, A.C.M. Avaliação da qualidade da proteina de levedura seca (Saccharomyces cerevisiae - sp.). In: REUNI ÃO ANUAL DA SOCIEDADE BRASILEIRA DE ZOOTECNIA, 20, Pelotas, 1983. Anais. Pelatas, S. B.Z., 1983. p. 119.

MATTOS, W.R.S.; D'ARCE, R.D.,; MACHADO, P.F. El uso de levadura.de fermentacion alcohólica en la alimentación de los ruminantes. In: GRUPO DE PAISES LATINO AMERICANOS Y DEL CARIBE EXPORTADORES DE AZUCAR. Uso Alternativo de la caña de azúcar para energia y alimento. Mexico, GEPLACEA, 1987. p. $113-23$.

MEEKER, E. W. \& WAGNER, E.C. Titration of ammonia in presence of boric acid. Industrial and Engineering Chemistry. Aralitical Edition, Easton, 5(6): 396-8, Nov., 1933.

MENEZES, T.J.B. \& HIOSHII, S.H. Efeito do tratamento do bagaço de cana. na extensão da hidrolise da celulose. Coletanea do ITAL, Campinas, 12: 123-35, $1981 / 82$. 
85.

MENTEM, J.F.M. ; LIMA, G.J.M.M. ; PAKER, I.U. ; MIYADA, V.S. ; LAVORENTI, A. Niveis de uréia e ácido úrico no sangue de porcas alimentadás com raçōes contendo levedura seca. In: REUNÃO ANUAL DA SOCIEDADE BRASILEIRA DE ZOOTECNIA, 21 , Belo Horizonte, 1984. Anais, Belo Horizonte, S.B.Z., 1984. p. 204.

MIYADA, V.S. Uso da levedura seca (Saccharomyces cerevisiae) de destilarias de álcool de cana-de-açúcar na alimentaçăo de suinos em crescimento e acabamento. Piracicaba, 1978. 106 p. CMestrado - Escola Superior de Agricultura "Luiz de Queiroz"/USP).

MIYADA, V.S. : \& LAVORENTI, A. . Uso da levedura seca (Saccharomyces cerevisiae) de destilarias de álcool de cana-de-açúcar na alimentação de suinos em crescimento e acabamento. Revista da Sociedade Brasileira de Zootecnia, Viçosa, 8(3): 497-515, 1979.

MOREIRA, J.R.A. Uso da levedura seca cSaccharomyces cerevisiae) de destilarias de álcool de cana-de-açúcar em raçôes isocalóricas para suinos em crescimento e acabamento. Piracicaba, 1984: 107 p. CMestrado - Escola Superior de Agricultura. "Luiz de Queiroz"/USP).

MOURA, E.C.V.; BATISTA, M.; MENDES, A. A. Efeito da substituição da protéina de carne epou do peixe pela biomassa protéica, na alimentaçăo de frangos de corte. Int REUNI ̃̃o ANUAL DA SOCIEDADE BRASILEIRA DE ZOOTECNIA, 19. , Piracicaba, 1982. Anais, Piracicaba, S. B. Z., 1982. p. 24.

OLIVEIRA, E.R.; VALSECHI, O.; STUPIELLO, J.P.; DELGADO, A. A. ; C.ESAR, M. A.A.; NOVAES, F.V. Elementos de controle químico das Usinas de Açúcar de Cana. Piracicaba, ESALQ Departamento Tecnologia Rural, 1974. $140 \mathrm{p}$. 
86.

PASSOS, D.M. ; ROMANUS, O. ; CAMPELLO, J.P. Tecnicas analiticas para controle de fermentaçöes. In: BACILA, M. Curso de fisiologia de microrganismos. Curitiba, s. ed., 1960. p. $14-5$.

PATURAU, J.M. Bagasse. In: _- By-products of the Cane Sugar Industry. Amsterdam. Elsevier, 1969 . cap. 3, p. $25-42$.

PAYNE, J.H. ed. Sugar cane factory analytical control. Amsterdam, Elsevier, $1968.190 \mathrm{p}$.

PEPPLER, H.J. Food yeasts. In: ROSE, A.H. \& HARRISON, J.S. The yeasts. New York, Academic Press, 1970. v. 3, cap. 8, p. $421-62$.

PETERSON, W. H. ; SNELL, J.F.; FRAIZER, W.C. Fodder yeast firom wood sugar.. Industrial and Engineering Chemistry, Washington, 37(1): 30-5. Jan. 1945.

PETROVIC, S. Influence of furfural on the assimilation rate sugars and on the yeast activity in synthetic and hidrolysed media. Drev. Yysk, 2: 67-78, 1969. Apud Chemical Abstracts, Easton, 72(3): 208, ref. 11376, 1970 . (Resumo).

PEZZATO, A.C. Utilização de levedura na al i mentação de monogásticos; I. Aves. In: SEMANA DE ZOOTECNIA, 6. ; SIMPOSIO SOBRE APROVEI TAMENTO DE SUBPRODUTOS DA AGROINDÚSIRIA NA ALI MENTAÇÃO ANIMAL, 1., Botucatu, 1985. Anais. Botucatu, UNESP, 1985 . p. $37-55$.

PEZZATO, L.E.; POLANO, S. A. ; SAUCEDO, E.C.A. ; FAUSTINI FILHO, S.T.; FRE, C.A. Levedura seca (Saccharomyces cereviside) de álcool de cana-de-açúcar na alimertação de frangos de corte. In: REUNÃO ANUAL DA SOCIEDADE BRASILEIRA DE ZODTECNIA, 19. Piracicaba, 1982. Anais. Piracicaba, SEZ., 1982. p. 25. 
87.

PYKE, M. Food science and tecnology. London, John Murray, 1964. $211 \mathrm{p}$.

RAMOS, C. Influence of $\mathrm{pH}$ and of some bases on the fermentation of chemical hydrolysates. Rer. Ciencias Biológicas, 14(1): 11-6, 1983. Apud Tate \& Lyles's Sugar Industry Abstracts, Brussels, 47(5): 181, Sept. /Oct. 1985. (Resumo).

RAMOS, C. ; LOPES, R. ; LLERENA, L, Study of batch fermentation with candida utilis $Y-900$ in chemicas prohydrolysates from pith. Rev. Ciências Biológicas, 10(2): $301-11,1979$. Apud Tate \& Lyles's Sugar Industry Abstracts, Brussels, 44(3): 99, May/June, 1982 . (Resumo).

RAMOS, C.; NAPOLES, I.; LOPES, R.; Improved production of yeasts from hydrolytic syrup in order to evaluate its nutricional quality. Rer. Ciências Biológicas, $14(4)$ : 17-25, 1983. Apud Tate \& Lyles's Sugar Industry Abstracts, Brussels, 47(5): 181, Sept. (Oct. 1985. (Resumo).

SALES, A.M.; MENEZES, T. J.B. ; OKADA, M. ; ARAKAKI, T. LAMO, P.R. Produção e avaliação nutricional de biomassa protéica de levedura em melaço. Coletânea do Instituto de Tecnologia de Alimentos, Campinas, 8: 443-55, 1977.

SLAGLE, S.P. \& ZIMMERMAN, D.R. Evaluation of yeast single cell protein with young pigs. Journal of Animal Science, Champaign, 49(5): 1252-60, 1979.

SLININGER, P.J.; BOTHAST, R. J. ; VAN CAUWENBERGE, J.E. ; KURIZMAN, C.P. Convertation of D-xylose to ethanol by the yeast Pachysolen tannophilus. Biotechnology and Bioengineering, New York, 24(2): 371-84, Feb. 1982. 
88.

STAKHORSKAYA, L.K. \& KATS, N.I. Effect of hidroxy-methylfurfural on yeast grown in continuous cultures. Sb. Tr. Vses. Nauch. - Issled. Inst. Gidroliza Rast. Mater, 17:97-101, 1968. Apud Chemical Abstracts Easton, 72( 3$)$ : 103, ref. 10240,1970 . (Resumo).

STAMFORD, T.L.M. Utilização do licor residual de pré-hidrólise do bagaço de cana-de-açúcar para produção de proteina microbiana por - Aspergillus Niger Van Tieghen. Piracicaba, 1979. 92 p. CMestrado - Escola Superior de Agricultura "Luiz de Queiroz" $/$ USP).

TAMBURO, M.E.; GINTERS, K. M. ; LUCHESE, L. ; ARRIGONI, M. B. ; PEZZATO, A.C. 'Efeito da adição de diferentes níveis de levedura (Saccharomyces cerevisiae) de álcool de cana-de-açúcar, sobre a umidade das excretas de frangos de corte. In: REUNI ÃO ANUAL DA S.B.Z., 19., Piracicaba, 1982. Anais, Piracicaba, S. B. 2., 1982. p. 26.

TRAN, A. V. \& CHAMBERS, R.P. EThanol fermentation of red oak acid prehydrolysate by the yeast pichia stipitis CBS 5776. Enzyme Microbiology and Technology, Stoneham, 8: $439-44,1986$.

VALSECHI, 0 . Tecnologia da celulose do bagaço de cana-de-açúcar para papel; estudos relatiovos à influencia da medula. Piracicaba. 1964. 288 p. CCátedra - Escola Superior de Agricultura "Luiz de Queiroz"/USP).

VANANUVAT, P. \& KINSELLA, J. E. Amino: acid composition of protein isolates from Saccharomyces fragilis. Journal of Agriculture and Food Chemistry, Easton, 23( 3): 595-7, 1975.

VILLALON, R. \& 'TAGLE,' M. A. Las levaduras como recursos proteicos de la dieta humana, algunos aspectos de su problematica. ICIDCA, Habana, 7(3): 3-12, 1973. 
89.

VILLELA, G. G.; BACILA, M. ; TASTALDI, H. Técnica e experimento de bioquímica. Rio de Janeiro, Guanabara Koogan, 1973. 552 p.

WALDROUP, P.W. \& HAZEN, K.R. Yeast grown on hydrocarbon fractions as a protein source in the diet of laying hens. Poultry Science, Ithaca, 54: 635-7, 1975.

WEI GERT, B. ; KLEIN, C. ; RIZZI, M. LAUTERBACH, C. ; DELLWEG, H. Xylose fermentation by yeasts, 8. Influence of furfural on the aerobic growth of the yeast. Pichia sitpilis. Biotechnology Letters, new York, 10(12): 895-900, 1988.

WHITE, J. Bakers' yeast, Historical: yeast physiology and nutrition. In: WHITE, J. Yeast technology. London, Chap. man and Hall, 1954 . cap. 2, p. 12-26. 